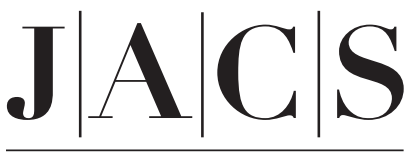

A R T I C L E S

Published on Web 12/31/2005

\title{
Studies of Low-Coordinate Iron Dinitrogen Complexes
}

\author{
Jeremy M. Smith, ${ }^{\dagger, \ddagger}$ Azwana R. Sadique, ${ }^{\dagger}$ Thomas R. Cundari, ${ }^{*, \S}$ \\ Kenton R. Rodgers, ${ }^{*}, \|$ Gudrun Lukat-Rodgers," Rene J. Lachicotte, ${ }^{\dagger}$ \\ Christine J. Flaschenriem, ${ }^{\dagger}$ Javier Vela ${ }^{\dagger}$ and Patrick L. Holland ${ }^{*, \dagger}$ \\ Contribution from the Department of Chemistry, University of Rochester, Rochester, New York \\ 14267, Department of Chemistry, University of North Texas, Denton, Texas 76203, and \\ Department of Chemistry and Molecular Biology, North Dakota State University, \\ Fargo, North Dakota 58105
}

Received April 26, 2005; E-mail: holland@chem.rochester.edu

\begin{abstract}
Understanding the interaction of $\mathrm{N}_{2}$ with iron is relevant to the iron catalyst used in the Haber process and to possible roles of the FeMoco active site of nitrogenase. The work reported here uses synthetic compounds to evaluate the extent of NN weakening in low-coordinate iron complexes with an FeNNFe core. The steric effects, oxidation level, presence of alkali metals, and coordination number of the iron atoms are varied, to gain insight into the factors that weaken the NN bond. Diiron complexes with a bridging

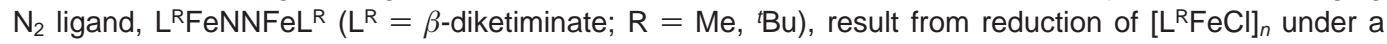
dinitrogen atmosphere, and an iron(I) precursor of an $\mathrm{N}_{2}$ complex can be observed. X-ray crystallographic and resonance Raman data for $L^{R} F e N N F e L^{R}$ show a reduction in the $\mathrm{N}-\mathrm{N}$ bond order, and calculations (density functional and multireference) indicate that the bond weakening arises from cooperative backbonding into the $\mathrm{N}_{2} \pi^{*}$ orbitals. Increasing the coordination number of iron from three to four through binding of pyridines gives compounds with comparable $\mathrm{N}-\mathrm{N}$ weakening, and both are substantially weakened relative to five-coordinate iron- $\mathrm{N}_{2}$ complexes, even those with a lower oxidation state. Treatment of

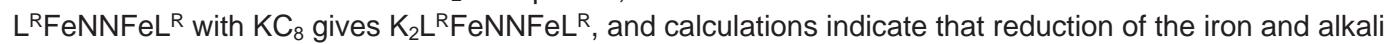

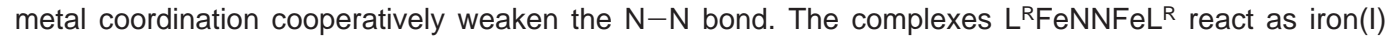
fragments, losing $\mathrm{N}_{2}$ to yield iron(I) phosphine, $\mathrm{CO}$, and benzene complexes. They also reduce ketones and aldehydes to give the products of pinacol coupling. The $\mathrm{K}_{2} \mathrm{~L}^{\mathrm{R}} \mathrm{FeNNFeL^{R }}$ compounds can be alkylated at iron, with loss of $\mathrm{N}_{2}$.
\end{abstract}

\section{Introduction}

Atmospheric $\mathrm{N}_{2}$ is an abundant and cheap source of nitrogen for nitrogen-containing compounds. However, the $\mathrm{N}_{2}$ molecule is difficult to manipulate due to both thermodynamic factors $\left(\mathrm{N} \equiv \mathrm{N}\right.$ bond strength of $944 \mathrm{~kJ} \mathrm{~mol}^{-1}$; negative electron affinity; high ionization energy) and kinetic factors (poor electrophilicity and nucleophilicity; no permanent dipole). ${ }^{1}$ Catalysts are used in nature and industry to activate $\mathrm{N}_{2}$, and the largest-scale processes use iron.

In nature, the nitrogenase enzymes ${ }^{2}$ catalyze the reduction of atmospheric dinitrogen to ammonium salts, which are in turn

\footnotetext{
†niversity of Rochester.

$\doteqdot$ Current address: Department of Chemistry and Biochemistry, New Mexico State University, Las Cruces, NM 88003.

$\S$ University of North Texas.

"North Dakota State University.

(1) Hidai, M.; Mizobe, Y. Chem. Rev. 1995, 95, 1115-1133. (b) Fryzuk, M. D.; Johnson, S. A. Coord. Chem. Rev. 2000, 200-202, 379-409. (c) Gambarotta, S.; Scott, J. Angew. Chem., Int. Ed. 2004, 43, 5298-5308. (d) MacKay, B. A.; Fryzuk, M. D. Chem. Rev. 2004, 104, 385-401.

(2) Burgess, B. K. Chem. Rev. 1990, 90, 1377-1406. (b) Burgess, B. K.; Lowe, D. J. Chem. Rev. 1996, 96, 2983-3011. (c) Howard, J. B.; Rees, D. C. Chem. Rev. 1996, 96, 2965-2982. (d) Rees, D. C.; Howard, J. B. Curr. Opin. Chem. Biol. 2000, 4, 559-566. (e) Barrière, F. Coord. Chem. Rev. 2003, 236, 71-89. (f) Holland, P. L., "Nitrogen Fixation," in Comprehensive Coordination Chemistry II, McCleverty, J.; Meyer, T. J., Eds. Elsevier: Oxford, 2004; Vol. 8, pp 569-599.
}

756 - J. AM. CHEM. SOC. 2006, 128, 756-769 used in the biosynthesis of nitrogen-containing molecules. Iron is the only transition metal present in all nitrogenase enzymes, ${ }^{3,4}$ but iron-molybdenum nitrogenase is the best characterized. In iron-molybdenum nitrogenase, the site of substrate binding and reduction is the iron-molybdenum cofactor or "FeMoco" (Figure 1). The most recent X-ray crystallographic study of the enzyme (1.16 $\AA$ resolution) shows the FeMoco in the native state to be a $\mathrm{MoFe}_{7} \mathrm{~S}_{9} \mathrm{X}$ cluster, ${ }^{5}$ and Mössbauer data indicate an $\left(\mathrm{Fe}^{3+}\right)_{3}\left(\mathrm{Fe}^{2+}\right)_{4}\left(\mathrm{Mo}^{4+}\right)$ oxidation level. ${ }^{6}$ The six iron atoms in the center are bridged by a light atom $\mathrm{X}(\mathrm{C}, \mathrm{N}$, or $\mathrm{O}){ }^{5,6 \mathrm{~b}, 7}$

(3) Iron-vanadium nitrogenase: (a) Robson, R. L.; Eady, R. R.; Richardson, T. H.; Miller, R. W.; Hawkins, M.; Postgate, J. R. Nature 1986, 322, 388390. (b) Arber, J. M.; Dobson, B. R.; Eady, R. R.; Stevens, P.; Hasnain, S. S.; Garner, C. D.; Smith, B. E. Nature 1987, 325, 372-374. (c) Morningstar, J. E.; Hales, B. J. J. Am. Chem. Soc. 1987, 109, 6854-6855. (d) Morningstar, J. E.; Johnson, M. K.; Case, E. E.; Hales, B. J. Biochemistry 1987, 26, 1795-1800. (e) Arber, J. M.; Dobson, B. R.; Eady, R. R. Hasnain, S. S.; Garner, C. D.; Matsushita, T.; Nomura, M.; Smith, B. E. Biochem. J. 1989, 258, 733-737. (f) Eady, R. R. Chem. Rev. 1996, 96, 3013-3030. (g) Rehder, D. J. Inorg. Biochem. 2000, 80, 133-136. (h) Eady, R. R. Coord. Chem. Rev. 2003, 237, 23-30.

(4) Iron-only nitrogenase: (a) Müller, A.; Schneider, K. Knüttel, K.; Hagen, W. R. FEBS Lett. 1992, 303, 36-40. (b) Schneider, K.; Gollan, U; Dröttboom, M.; Selsemeier-Voigt, S.; Müller, A. Eur. J. Biochem. 1997, 244, 789-800. (c) Siemann, S.; Schneider, K.; Drottboom, M.; Muller, A. Eur. J. Biochem. 2002, 269, 1650-1661. (d) Krahn, E.; Weiss, B. J. R.; Krockel, M.; Groppe, J.; Henkel, G.; Cramer, S. P.; Trautwein, A. X.; Schneider, K.; Muller, A. J. Biol. Inorg. Chem. 2002, 7, 37-45.

(5) Einsle, O.; Tezcan, F. A.; Andrade, S. L. A.; Schmid, B.; Yoshida, M.; Howard, J. B.; Rees, D. C. Science 2002, 297, 1696-1700. 


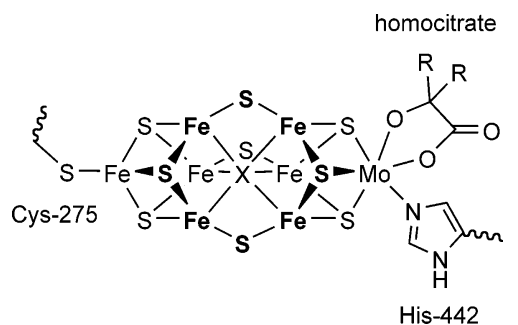

Figure 1. FeMo cofactor "FeMoco" of iron-molybdenum nitrogenase in the native form. $\mathrm{X}=\mathrm{C}, \mathrm{N}$ or $\mathrm{O}$.

Spectroscopic investigations with ${ }^{15} \mathrm{~N}_{2}{ }^{8}$ and the spectroscopic similarity of active and inactive forms of the enzyme ${ }^{2}$ argue against the interstitial atom resulting from splitting of $\mathrm{N}_{2}$, suggesting that its role may be structural.

The picture in Figure 1 is not strictly relevant to $\mathrm{N}_{2}$ binding by the FeMoco, because the crystallographically characterized native state of the FeMoco does not bind substrates. Several reducing equivalents are required before $\mathrm{N}_{2}$ binds. ${ }^{9}$ ENDOR studies of mutant enzymes are most consistent with binding of products at the central iron atoms. ${ }^{10}$ These results are most easily interpreted within a model where reduction and substrate binding are coupled to cleavage and formation of bonds between iron and $\mathrm{X} .{ }^{11,12}$ Recent computational studies support this idea, $6 \mathrm{~b}, 7 \mathrm{~d}, \mathrm{e}, 10 \mathrm{~g}$ and one has even located low-energy transition states for each proposed step of $\mathrm{N}_{2}$ binding and activation. ${ }^{7 \mathrm{~d}}$ Interestingly, in this mechanism, the FeMoco breaks open at one bridging sulfide to bind $\mathrm{N}_{2}$ as an $\mathrm{Fe}-\mathrm{NN}-\mathrm{Fe}$ intermediate, and this intermediate is subsequently protonated by a thiol, in a

(6) (a) Yoo, S. J.; Angove, H. C.; Papaefthymiou, V.; Burgess, B. K.; Münck, E. J. Am. Chem. Soc. 2000, 122, 4926-4936. (b) Vrajmasu, V.; Münck, E.; Bominaar, E. L. Inorg. Chem. 2003, 42, 5974-5988.

(7) Calculations support the idea that $X$ is a nitrogen atom: (a) Dance, I. Chem Commun. 2003, 324-325. (b) Hinnemann, B.; Norskov, J. K. J. Am. Chem. Soc. 2003, 125, 1466-1467. (c) Lovell, T.; Liu, T.; Case, D. A.; Noodleman, L. J. Am. Chem. Soc. 2003, 125, 8377-8383. (d) Schimpl, J.; Petrilli, H. M.; Blöchl, P. E. J. Am. Chem. Soc. 2003, 125, 15772-15778. (e) Huniar, U.; Ahlrichs, R.; Coucouvanis, D. J. Am. Chem. Soc. 2004 126, 2588-2601. (f) Hinnemann, B.; Norskov, J. K J. Am. Chem. Soc. 2004, 126, 3920-3927. However, recent ENDOR and ESEEM studies argue strongly against nitrogen as X: Yang, T.-C.; Maeser, N. K.; Laryukhin, M.; Lee, H.-I.; Dean, D. R.; Seefeldt, L. C.; Hoffman, B. M. J. Am. Chem. Soc. 2005, 127, 12804-12805.

(8) (a) Thomann, H.; Morgan, T. V.; Jin, H.; Burgmayer, S. J. N.; Bare, R. E.; Stiefel, E. I. J. Am. Chem. Soc. 1987, 109, 7913-7914. (b) Lee, H.-I.; Benton, P. M. C.; Laryukhin, M.; Igarashi, R. Y.; Dean, D. R.; Seefeldt, L. C.; Dean, D. R. J. Am. Chem. Soc. 2003, 125, 5604-5605.

(9) (a) Lowe, D. J.; Thorneley, R. N. F. Biochem. J. 1984, 224, 877-886. (b) Thorneley, R. N. F.; Lowe, D. J. Biochem. J. 1984, 224, 887-894. (c) Lowe, D. J.; Thorneley, R. N. F. Biochem. J. 1984, 224, 895-901. (d) Thorneley, R. N. F.; Lowe, D. J. Biochem. J. 1984, 224, 903-909.

(10) (a) Christiansen, J.; Dean, D. R.; Seefeldt, L. C. Annu. Rev. Plant Physiol. Plant Mol. Biol. 2001, 52, 269-295. (b) Benton, P. M. C.; Mayer, S. M. Shao, J.; Hoffman, B. M.; Dean, D. R.; Seefeldt, L. C. Biochemistry 2001 40, 13816-13825. (c) Benton, P. M. C.; Christiansen, J.; Dean, D. R.; Seefeldt, L. C. J. Am. Chem. Soc. 2001, 123, 1822-1827. (d) Mayer, S. M.; Niehaus, W. G.; Dean, D. R. J. Chem. Soc., Dalton Trans. 2002, 802807. (e) Benton, P. M. C.; Laryukhin, M.; Mayer, S. M.; Hoffman, B. M.; Dean, D. R.; Seefeldt, L. C. Biochemistry 2003, 42, 9102-9109. (f) Lee, H.-I.; Igarashi, R. Y.; Laryukhin, M.; Doan, P. E.; Dos Santos, P. C.; Dean, D. R.; Seefeldt, L. C.; Hoffman, B. M. J. Am. Chem. Soc. 2004, 126, $9563-$ 9569. (g) Igarashi, R. Y.; Dos Santos, P. C.; Niehaus, W. G.; Dance, I. G.; Dean, D. R.; Seefeldt, L.C. J. Biol. Chem. 2004, 279, 34770-34775. (h) Barney, B. M.; Igarashi, R.Y.; Dos Santos, P. C.; Dean, D. R.; Seefeldt, L. C. J. Biol. Chem. 2004, 279, 53621-53624. (i) Dos Santos, P. C.; Igarashi, R. Y.; Lee, H.-I.; Hoffman, B. M.; Seefeldt, L. C.; Dean, D. R. Acc. Chem. Res. 2005, 38, 208-214. (j) Barney, B. M.; Laryukhin, M.; Igarashi, R. Y.; Lee, H.-I.; Dos Santos, P. C.; Yang, T.-C.; Hoffman, B. M.; Dean, D. R.; Seefeldt, L. C. Biochemistry 2005, 44, 8030-8037. (k) Igarashi, R. Y.; Laryukhin, M.; Dos Santos, P. C.; Lee, H.-I.; Dean, D. R.; Seefeldt, L. C.; Hoffman, B. M. J. Am. Chem. Soc. 2005, 127, 6231-6241.

(11) Seefeldt, L. C.; Dance, I. G.; Dean, D. R. Biochemistry 2004, 43, 14011409

(12) The role of X may be to reversibly coordinate to iron in the native form but release low-coordinate iron in reduced forms of the cofactor: Holland, P. L. Can. J. Chem. 2005, 83, 296-301. manner reminiscent of proposals by Sellmann. ${ }^{13}$ A very recent study shows a single $\mathrm{N}$ environment for an apparent adduct of $\mathrm{N}_{2}$ (or reduced form thereof) on the FeMoco, which is consistent with a symmetrical binding mode. ${ }^{14}$

In addition to nitrogenase, there are heterogeneous iron systems that catalytically reduce dinitrogen. Some iron oxide ${ }^{15}$ and iron sulfide ${ }^{16}$ surfaces produce ammonia from $\mathrm{N}_{2}$. Most industrially relevant is the Haber-Bosch process, in which ammonia is synthesized from nitrogen and hydrogen over an iron catalyst. ${ }^{17}$ Single-crystal iron surfaces reduce $\mathrm{N}_{2}$, and the (111) face of iron is most active. ${ }^{18}$ LEED experiments suggest that $\mathrm{N}_{2}$ bound to $\mathrm{Fe}(111)$ is strongly inclined rather than perpendicular to the surface. ${ }^{19}$ Therefore, $\mathrm{N}_{2}$ bridged between iron atoms is again a potential binding mode.

Despite the importance of these iron catalysts, the current understanding of $\mathrm{N}_{2}$ reduction chemistry in synthetic iron compounds is rudimentary. Some solution $\mathrm{Fe}-\mathrm{N}_{2}$ systems have been reported to give hydrazine or ammonia upon protonation, ${ }^{20-22}$ but these systems are not understood at a mechanistic level. For example, uncharacterized mixtures of iron(III) chloride and strong reducing agents are reported to give hydrazine upon protonation. ${ }^{20}$ Treatment of some iron-phosphine $-\mathrm{N}_{2}$ complexes with excess acid gives limited amounts of ammonia. ${ }^{23}$ In a well-characterized recent study, the reduced dinitrogen complex $\mathrm{Fe}\left(\mathrm{PhBP}^{i \mathrm{Pr}}{ }_{3}\right)\left(\mathrm{N}_{2}\right) \mathrm{MgCl}(\mathrm{THF})_{2}\left(\mathrm{PhBP}_{3} \mathrm{Pr}_{3}=\right.$ $\left.\mathrm{PhB}\left(\mathrm{CH}_{2} \mathrm{P}^{i} \mathrm{Pr}_{2}\right)_{3}{ }^{-}\right)$reacts with electrophiles to give a diazenido ligand derived from dinitrogen. ${ }^{24}$

One important difference between the catalytic iron sites and synthetic iron compounds is the coordination number at iron, which is typically 5 or 6 for synthetic compounds but possibly lower in the active forms of the catalysts. Because the bulky $\beta$-diketiminate ligands, $\mathrm{L}^{\mathrm{Me}}$ and $\mathrm{L}^{t \mathrm{Bu}}$ (Figure 2) stabilize synthetic complexes with three-coordinate and four-coordinate iron centers, ${ }^{12}$ it is possible to evaluate the importance of iron coordination number. Here, we show that when $\mathrm{N}_{2}$ binds to lowcoordinate iron, the $\mathrm{N}-\mathrm{N}$ bond becomes much weaker than in other iron- $\mathrm{N}_{2}$ complexes. Further, we evaluate the structural

(13) Sellmann, D.; Sutter, J. Acc. Chem. Res. 1997, 30, 460-469.

(14) Barney, B. M.; Yang, T.-C.; Igarashi, R. Y.; Dos Santos, P. C.; Laryukhin, M.; Lee, H.-I.; Hoffman, B. M.; Dean, D. R.; Seefeldt, L. C. J. Am. Chem. Soc. 2005, 127, 14960-14961.

(15) Brandes, J. A.; Boctor, N. Z.; Cody, G. D.; Cooper, B. A.; Hazen, R. M. Yoder, H. S. Nature 1998, 395, 365-367.

(16) Dörr, M.; Käbbohrer, J.; Grunert, R.; Kreisel, G.; Brand, W. A.; Werner, R. A.; Geilmann, H.; Apfel, C.; Robl, C.; Weigand, W. Angew. Chem., Int. Ed. 2003, 42, 1540-1543.

(17) Jennings, J. R. Catalytic Ammonia Synthesis: Principles and Practice Plenum: New York, 1991.

(18) (a) Dumesic, J. A.; Topsøe, H.; Boudart, M. J. Catal. 1975, 37, 513-522. (b) Spencer, N. D.; Schoonmaker, R. C.; Somorjai, G. J. Catal. 1982, 74 129-135. (c) Falicov, L. M.; Somorjai, G. A. Proc. Natl. Acad. Sci. U.S.A 1985, 82, 2207-2211.

(19) (a) Grunze, M.; Golze, M.; Hirschwald, W.; Freund, H. J.; Pulm, H.; Seip, U.; Tsai, M. C.; Ertl, G.; Kueppers, J. Phys. Rev. Lett. 1984, 53, 850853. (b) Freund, H. J.; Bartos, B.; Messmer, R. P.; Grunze, M.; Kuhlenbeck, H.; Neumann, M. Surf. Sci. 1987, 185, 187-202.

(20) (a) Borodko, Y. G.; Broitman, M. O.; Kachapina, L. M.; Shilov, A. E. Ukhin, L. Y. J. Chem. Soc. D, Chem. Commun. 1971, 1185-1186. (b) Bazhenova, T. A.; Ivleva, I. N.; Kachapina, L. M.; Shilova, A. K.; Shilov, A. E.; Tchoubar, B. J. Organomet. Chem. 1985, 296, 95-101. (c) Bazhenova, T. A.; Kachapina, L. M.; Shilov, A. E.; Antipin, M. Y.; Struchkov, Y. T. J. Organomet. Chem. 1992, 428, 107-123.

(21) Yamamoto, A.; Miura, Y.; Ito, T.; Chen, H.-L.; Iri, K.; Ozawa, F.; Miki, K.; Sei, T.; Tanaka, N.; Kasai, N. Organometallics 1983, 2, 1429-1436.

(22) (a) Hughes, D. L.; Leigh, G. J.; Jimenez-Tenorio, M.; Rowley, A. T. J. Chem. Soc., Dalton Trans. 1993, 75-82. (b) Leigh, G. J.; Jimenez-Tenorio, M. J. Am. Chem. Soc. 1991, 113, 5862-5863. (c) Hall, D. A.; Leigh, G. J. J. Chem. Soc., Dalton Trans. 1996, 3539-3541.

(23) (a) George, T. A.; Rose, D. J.; Chang, Y; Chen, Q.; Zubieta, J. Inorg. Chem. 1995, 34, 1295-1298. (b) Gilbertson, J. D.; Szymczak, N. K.; Tyler, D. R. J. Am. Chem. Soc. 2005, 127, 10184-10185.

(24) Betley, T. A.; Peters, J. C. J. Am. Chem. Soc. 2003, 125, 10782-10783. 


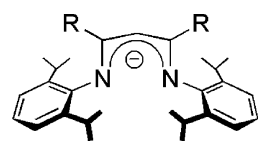

Figure 2. $\beta$-Diketiminate ligands used in this study. These are abbreviated $\mathrm{L}^{\mathrm{Me}}$ for $\mathrm{R}=\mathrm{CH}_{3}$ and $\mathrm{L}^{\mathrm{tBu}}$ for $\mathrm{R}=\mathrm{C}\left(\mathrm{CH}_{3}\right)_{3}$.

\section{Scheme 1}

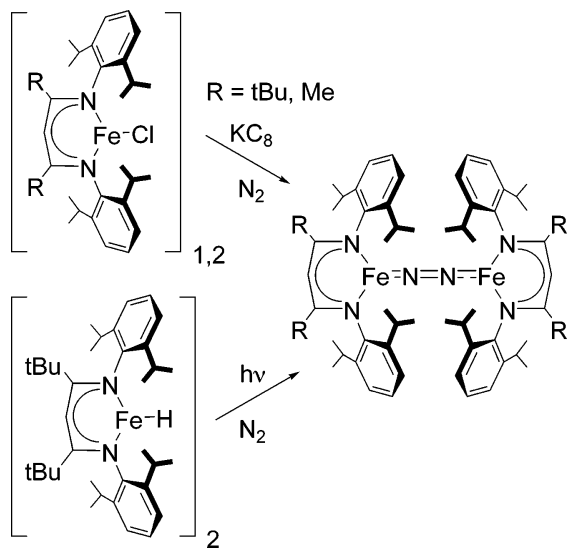

and spectroscopic effects of changes in oxidation level, coordination number, and steric bulk. The unusual $\mathrm{N}_{2}$ complexes are characterized through structural, spectroscopic, and theoretical methods, as well as their characteristic reactivity patterns.

\section{Results}

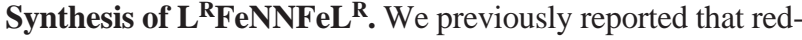
purple $\mathrm{L}^{t \mathrm{Bu}} \mathrm{FeNNFe}{ }^{t \mathrm{Bu}}$ could be prepared from $\mathrm{L}^{t \mathrm{Bu}} \mathrm{FeCl}$ by reduction with sodium naphthalenide. ${ }^{25}$ Potassium/graphite $\left(\mathrm{KC}_{8}\right)$ has proven to be a more effective reducing agent for $\mathrm{L}^{t \mathrm{Bu}} \mathrm{FeCl}$ and $\left[\mathrm{L}^{\mathrm{Me}} \mathrm{Fe}(\mu-\mathrm{Cl})\right]_{2}$, leading to $\mathrm{L}^{t \mathrm{Bu}} \mathrm{FeNNFeL}{ }^{t \mathrm{Bu}}$ and $\mathrm{L}^{\mathrm{Me}} \mathrm{FeNNFeL}{ }^{\mathrm{Me}}$ in about $70 \%$ yield (Scheme 1$){ }^{26} \mathrm{~L}^{t \mathrm{Bu}} \mathrm{FeNN}-$ $\mathrm{FeL}^{t \mathrm{Bu}}$ is also produced by photolysis ( $4 \mathrm{~d}$, RT, high-pressure mercury lamp) of $\left[\mathrm{L}^{t \mathrm{Bu}} \mathrm{FeH}\right]_{2}{ }^{46}$ under an $\mathrm{N}_{2}$ atmosphere.

We have reported the X-ray crystal structure of $\mathrm{L}^{t \mathrm{Bu}} \mathrm{FeNNFeL}{ }^{t \mathrm{Bu}} .{ }^{25}$ Only seven resonances are observed in its ${ }^{1} \mathrm{H}$ NMR spectrum $\left(\mathrm{C}_{6} \mathrm{D}_{6}\right)$, suggesting that the diketiminate ligand contains two mirror planes, and the molecule has averaged $D_{2 h}$ or $D_{2 d}$ symmetry in solution. The ${ }^{1} \mathrm{H}$ NMR spectrum can be assigned on the basis of integration, chemical shift and relaxation time ( $T_{2}$ from width of peaks). Although highly sensitive to air and moisture, solutions of $\mathrm{L}^{t \mathrm{Bu}} \mathrm{FeNNFe} \mathrm{L}^{t \mathrm{Bu}}$ show no evidence of decomposition after several hours of heating in aromatic solvents at $100{ }^{\circ} \mathrm{C}$. $\mathrm{L}^{\mathrm{Me}} \mathrm{FeNNFeL}{ }^{\mathrm{Me}}$, on the other hand, reacts with aromatic solvents (see below).

We have obtained two different X-ray crystal structures of $\mathrm{L}^{\mathrm{Me}} \mathrm{FeNNFeL}{ }^{\mathrm{Me}}$ (Figure 3). In one crystal (1a), a disordered pentane molecule lies in the unit cell, and the other crystal (1b) is free of solvent. The two crystal structures give similar bond distances, which are similar to those in $\mathrm{L}^{t \mathrm{Bu}} \mathrm{FeNNFeL}{ }^{t \mathrm{Bu}}$ (Table 1). The $\mathrm{N}-\mathrm{N}$ bond lengths in $\mathrm{L}^{\mathrm{Me}} \mathrm{FeNNFeL}{ }^{\mathrm{Me}}$ are $1.18 \pm 0.01$ $\AA$, indicative of substantial $\mathrm{N}-\mathrm{N}$ bond weakening relative to free $\mathrm{N}_{2}(1.098 \AA)$. The iron-diketiminate ligand planes in $\mathrm{L}^{\mathrm{Me}} \mathrm{FeNNFeL}{ }^{\mathrm{Me}}$ are coplanar in each form of $\mathrm{L}^{\mathrm{Me}} \mathrm{FeNNFeL}{ }^{\mathrm{Me}}$, in contrast to the nearly perpendicular ligand planes in the crystal

(25) Smith, J. M.; Lachicotte, R. J.; Pittard, K. A.; Cundari, T. R.; Lukat-Rodgers, G.; Rodgers, K. R.; Holland, P. L. J. Am. Chem. Soc. 2001, 123, 92229223.

(26) Vela, J.; Stoian, S.; Flaschenriem, C. J.; Münck, E.; Holland, P. L. J. Am. Chem. Soc. 2004, 126, 4522-4523.
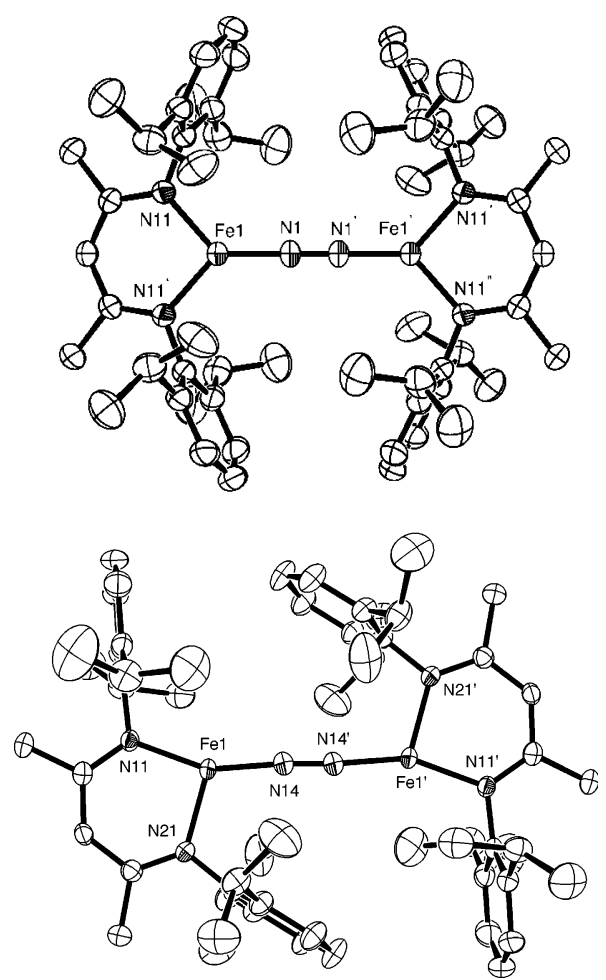

Figure 3. X-ray crystal structures of $\mathrm{L}^{\mathrm{Me}} \mathrm{FeNNFe} \mathrm{L}^{\mathrm{Me}}$. Top: pentane solvate in $C 2 / m$ (1a). Bottom: solvent-free crystal in $P 2_{1} / n$ (1b). Thermal ellipsoids shown at $50 \%$ probability, hydrogen atoms omitted for clarity. Selected bond lengths $(\AA)$ and angles $\left({ }^{\circ}\right)$ : $\mathrm{Fe}-\mathrm{N}\left(\mathrm{N}_{2}\right) 1.745(3)$ in $\mathbf{1 a}, 1.775(2)$ in 1b; Fe-N(diketiminate) 1.949(2) in 1a, 1.945(2) (N11) and 1.984(2) (N21) in $\mathbf{1 b} ; \mathrm{N}-\mathrm{N} 1.186(7)$ in $\mathbf{1 a}, 1.172(5)$ in $\mathbf{1 b} ; \mathrm{N}\left(\mathrm{N}_{2}\right)-\mathrm{Fe}-\mathrm{N}$ (diketiminate) $130.75(6)$ in 1a, 155.5(1) (N11) and 109.5(1) (N21) in 1b; N(diketiminate)$\mathrm{Fe}-\mathrm{N}$ (diketiminate) $97.6(1)$ in $\mathbf{1 a}, 94.8(1)$ in $\mathbf{1 b}$.

structure of $\mathrm{L}^{t \mathrm{Bu}} \mathrm{FeNNFe}{ }^{t \mathrm{Bu}}$ (the angle between the diketiminate planes is $\left.92.6^{\circ}\right) .{ }^{25} \mathrm{We}$ ascribe this difference to steric interactions between the two diketiminate ligands, because molecular mechanics calculations ${ }^{27}$ based on the crystallographic geometries of $\mathbf{1 a}$ and of $\mathrm{L}^{t \mathrm{Bu}} \mathrm{FeNNFeL}{ }^{t \mathrm{Bu}}$ suggest that the parallel geometry is more stable by $2 \mathrm{kcal} / \mathrm{mol}$ in the $\mathrm{L}^{\mathrm{Me}}$ complex, but less stable by $4 \mathrm{kcal} / \mathrm{mol}$ in the $\mathrm{L}^{t \mathrm{Bu}}$ complex. Interestingly, 1a and $\mathbf{1 b}$ differ by a surprising $20-25^{\circ}$ shift of the $\mathrm{N}_{2}$ ligand off of the line that bisects the diketiminate ligand. Apparently, the highly symmetric core found in 1a may be distorted by the small energy of crystal packing forces. The solution ${ }^{1} \mathrm{H}$ NMR spectrum of $1 \mathbf{a}$ in cyclohexane- $d_{12}$ is consistent with averaged $D_{2 h}$ or $D_{2 d}$ symmetry. The complex has a large magnetic moment in solution, $\mu_{\text {eff }}=7.9(3) \mu_{\mathrm{B}}$, which compares well with its $\mathrm{L}^{t \mathrm{Bu}}$ analogue $\left(8.4 \mu_{\mathrm{B}}\right)$.

The weakening of the $\mathrm{N}-\mathrm{N}$ bond is also observed by resonance Raman spectroscopy. A band at $1810 \mathrm{~cm}^{-1}$ in $\mathrm{L}^{\mathrm{Me}} \mathrm{FeNNFeL}{ }^{\mathrm{Me}}$ shifts to $1739 \mathrm{~cm}^{-1}$ in $\mathrm{L}^{\mathrm{Me}} \mathrm{Fe}^{15} \mathrm{~N}^{15} \mathrm{NFeL}^{\mathrm{Me}}$ (Figure 4A and 4B). Similar N-N bond weakening is observed in $\mathrm{L}^{t \mathrm{Bu}} \mathrm{FeNNFeL}{ }^{t \mathrm{Bu}}$, for which $v_{\mathrm{N}-\mathrm{N}}$ occurs at $1778 \mathrm{~cm}^{-1} \cdot{ }^{25}$ Both values are substantially decreased from free $\mathrm{N}_{2}\left(2331 \mathrm{~cm}^{-1}\right)$.

Computations: Ground-State Multiplicities. Our computational models for evaluation of iron-dinitrogen complexes with multiconfiguration (MCSCF) and density functional theory

(27) MM calculations were carried out with the MMFF94 force field (Halgren, T. A. J. Comput. Chem. 1996, 17, 616-641 and references therein) as implemented within the Spartan package (Spartan, Wavefunction, Inc., 18401 Von Karman Ave., Ste. 370, Irvine, CA 92612; http://www. wavefun.com). 
Table 1. $\mathrm{Fe}-\mathrm{N}, \mathrm{N}-\mathrm{N}$ Bond Lengths, and $\mathrm{N}-\mathrm{N}$ Bond Stretching Frequencies for Crystallographically Characterized Iron Complexes with Bridging $\mathrm{N}_{2}$

\begin{tabular}{|c|c|c|c|c|c|c|}
\hline complex & $\mathrm{Fe} \mathrm{CN}^{a}$ & $\begin{array}{c}\text { formal } \\
\text { oxidation } \\
\text { state of } \mathrm{Fe}\end{array}$ & $\mathrm{Fe}-\mathrm{N}(\AA \AA)$ & $\mathrm{N}-\mathrm{N}(\AA)$ & $\nu_{\mathrm{NN}}\left(\mathrm{cm}^{-1}\right)$ & ref \\
\hline$\left[\left(\mathrm{PEt}_{3}\right)_{2}(\mathrm{CO})_{2} \mathrm{Fe}\right]_{2} \mathrm{~N}_{2}$ & 5 & 0 & $1.87(1) ; 1.89(2)$ & $1.13(2)$ & \multirow{5}{*}{1770} & 42 \\
\hline$\left.\left[\left(\mathrm{P}(\mathrm{OMe})_{3}\right)_{2} \mathrm{CO}\right)_{2} \mathrm{Fe}\right]_{2} \mathrm{~N}_{2}$ & 5 & 0 & $1.876(9)$ & $1.13(1)$ & & 42 \\
\hline $\mathrm{L}^{\mathrm{Me}} \mathrm{Fe}\left({ }^{t} \mathrm{Bupy}\right) \mathrm{NN}\left({ }^{t} \mathrm{Bupy}\right) \mathrm{FeL}^{\mathrm{Me}}$ & 4 & 1 & $1.816(2)$ & $1.151(3)$ & & this work \\
\hline $\mathrm{L}^{t \mathrm{Bu}} \mathrm{Fe}\left({ }^{t} \mathrm{Bupy}\right) \mathrm{NN}\left({ }^{t} \mathrm{Bupy}\right) \mathrm{FeL}^{t \mathrm{Bu}}$ & 4 & 1 & $1.804(2) ; 1.794(2)$ & $1.161(4)$ & & this work \\
\hline$\left[\left(\mathrm{PhBP}^{i} \mathrm{Pr}_{3}\right) \mathrm{FeNNFe}\left(\mathrm{PhBP}^{i} \mathrm{Pr}_{3}\right)\right]^{-}$ & 4 & 0.5 & $1.813(2)$ & $1.171(4)$ & & 24 \\
\hline $\mathrm{L}^{\mathrm{Me}} \mathrm{FeNNFeL}{ }^{\mathrm{Me}}$ & 3 & 1 & $1.745(3)$ & $1.186(7)$ & \multirow[t]{2}{*}{1810} & \multirow[t]{2}{*}{ this work } \\
\hline & & & $1.775(2)$ & $1.172(5)$ & & \\
\hline $\mathrm{L}^{t \mathrm{Bu}} \mathrm{FeNNFeL} \mathrm{L}^{t \mathrm{Bu}}$ & 3 & 1 & $1.760(6) ; 1.778(6)$ & $1.192(6)$ & 1778 & 25 \\
\hline $\mathrm{K}_{2} \mathrm{~L}^{\mathrm{Me}} \mathrm{FeNNFeL}{ }^{\mathrm{Me}}$ & 3 & 0 & $1.741(5) ; 1.761(7)$ & $1.215(6)$ & 1625,1437 & this work \\
\hline $\mathrm{Na}_{2} \mathrm{~L}^{t \mathrm{Bu}} \mathrm{FeNNFe} \mathrm{L}^{t \mathrm{Bu}}$ & 3 & 0 & $1.749(3) ; 1.746(3)$ & $1.238(4)$ & 1583,1127 & 25 \\
\hline $\mathrm{K}_{2} \mathrm{~L}^{t \mathrm{Bu}} \mathrm{FeNNFe} \mathrm{L}^{t \mathrm{Bu}}$ & 3 & 0 & $1.773(7) ; 1.761(7)$ & $1.241(7)$ & 1589,1123 & 25 \\
\hline
\end{tabular}

${ }^{a}$ Coordination number at the iron atoms.

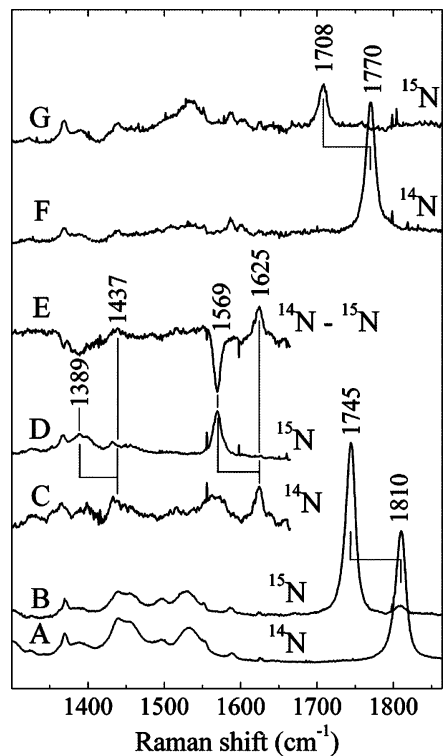

Figure 4. Resonance Raman spectra of FeNNFe complexes showing ${ }^{15} \mathrm{~N}$ sensitive bands. Based on the isotope shifts, bands above $1500 \mathrm{~cm}^{-1}$ are attributed to modes with dominant $\mathrm{N}-\mathrm{N}$ stretching character. A, $\mathrm{L}^{\mathrm{Me}} \mathrm{FeNNFeL}{ }^{\mathrm{Me}}$. B, $\mathrm{L}^{\mathrm{Me}} \mathrm{Fe}^{15} \mathrm{~N}^{15} \mathrm{NFeL}^{\mathrm{Me}}$. C, $\mathrm{K}_{2} \mathrm{~L}^{\mathrm{Me}} \mathrm{FeNNFeL}{ }^{\mathrm{Me}}$. D, $\mathrm{K}_{2} \mathrm{~L}^{\mathrm{Me}} \mathrm{Fe}^{15} \mathrm{~N}^{15} \mathrm{NFe}{ }^{\mathrm{Me}}$. E, Difference spectrum $\left[\mathrm{K}_{2} \mathrm{~L}^{\mathrm{Me}} \mathrm{FeNNFe}{ }^{\mathrm{Me}}-\right.$ $\left.\mathrm{K}_{2} \mathrm{~L}^{\mathrm{Me}} \mathrm{Fe}^{15} \mathrm{~N}^{15} \mathrm{NFeL}^{\mathrm{Me}}\right]$. F, $\mathrm{L}^{\mathrm{Me}} \mathrm{Fe}\left({ }^{t} \mathrm{BuPy}\right) \mathrm{NN}\left({ }^{t} \mathrm{BuPy}\right) \mathrm{FeL}^{\mathrm{Me}}$. G, $\mathrm{L}^{\mathrm{Me}} \mathrm{Fe}\left({ }^{t} \mathrm{BuPy}\right)-$ ${ }^{15} \mathrm{~N}^{15} \mathrm{~N}\left({ }^{t} \mathrm{BuPy}\right) \mathrm{FeL}{ }^{\mathrm{Me}}$. The spectra were obtained with $406.7 \mathrm{~nm}$ excitation. Samples A, B, F, and G were prepared in pentane. Samples C and D were prepared in toluene; toluene bands have been subtracted from the spectra.

(DFT) methods use a truncated diketiminate ligand $\mathrm{L}^{\prime}\left(\mathrm{C}_{3} \mathrm{~N}_{2} \mathrm{H}_{5}{ }^{-}\right){ }^{28}$ The starting geometry for calculations was derived from the experimental geometry of $\mathrm{L}^{t \mathrm{Bu}} \mathrm{FeNNFeL}^{t \mathrm{Bu}}$. After replacement of 2,6-diisopropylphenyl and tert-butyl substituents with hydrogen, the geometry was slightly modified to yield an idealized $D_{2 d}$ geometry in L'FeNNFeL'. To evaluate the cooperativity between iron centers, $\mathrm{L}^{\prime} \mathrm{FeNNFeL}$ ' was further trimmed to yield $\mathrm{L}^{\prime} \mathrm{FeNN}$ and $\left[\mathrm{L}^{\prime} \mathrm{FeNN}\right]^{-}$(each with $C_{2 v}$ symmetry), as shown in Chart 1 on the next page.

We find a ${ }^{4} \mathrm{~B}_{2}$ ground state for L'FeNN at the MRMP2/ SBKJC(d) level of theory, ${ }^{29}$ whereas the lowest energy doublet

(28) (a) Holland, P. L.; Cundari, T. R.; Perez, L. L.; Eckert, N. A.; Lachicotte R. J. J. Am. Chem. Soc. 2002, 124, 14416-14424. (b) Vela, J.; Vaddadi, S.; Cundari, T. R.; Smith, J. M.; Gregory, E. A.; Lachicotte, R. J.; Flaschenriem, C. J.; Holland, P. L. Organometallics 2004, 23, 5226-5239.

(29) For recent applications of this methodology to transition metal chemistry see: (a) Aikens, C. M.; Gordon, M. S. J. Phys. Chem. A 2003, 107, 104114. (b) Chung, G.; Gordon, M. S. Organometallics 2003, 22, 42-46. $\left({ }^{2} \mathrm{~B}_{2}\right)$ and sextet $\left({ }^{6} \mathrm{~B}_{2}\right)$ are 34 and $36 \mathrm{kcal} / \mathrm{mol}$ higher, respectively. MRMP2/SBKJC(d) calculations on the singly reduced $\left[\mathrm{L}^{\prime} \mathrm{FeNN}\right]^{-}$indicate an ${ }^{3} \mathrm{~A}_{1}$ ground state that is $39 \mathrm{kcal} / \mathrm{mol}$ below the ${ }^{1} \mathrm{~A}$ state and $49 \mathrm{kcal} / \mathrm{mol}$ below the lowest energy quintet $\left({ }^{5} \mathrm{~B}_{1}\right)$.

Single-point calculations on $\mathrm{L}^{\prime} \mathrm{FeNNFeL}$ ' and [L'FeNNFeL'] ${ }^{2-}$ were performed at the MCSCF level of theory. The MCSCF wave functions were converged within the $D_{2}$ subgroup of the full $D_{2 d}$ molecular symmetry of the diiron complexes due to program limitations. SBKJC(d)/FORS $(14,6)$ calculations indicate the ground state of $\mathrm{L}^{\prime} \mathrm{FeNNFeL}$ ' to be a septet $\left({ }^{7} \mathrm{~B}_{3}\right)$. This septet state of L'FeNNFeL' arises from ferromagnetic coupling of quartet L'FeNN fragments. However, the calculated manifold of states is dense: $E_{\text {relative }}(\mathrm{kcal} / \mathrm{mol})=0\left({ }^{7} \mathrm{~B}_{3}\right), 1\left({ }^{1} \mathrm{~A}\right), 3\left({ }^{5} \mathrm{~A}\right)$, $6\left({ }^{3} B_{3}\right)$. Because Mössbauer studies in progress ${ }^{30}$ and roomtemperature solution magnetic properties support a ferromagnetically coupled ground state, subsequent evaluation uses the ${ }^{7} \mathrm{~B}_{3}$ state.

Computations: Synergism between Iron Centers. Geometry optimization (B3LYP/CZDZ**++) of the neutral, quartet $\mathrm{L}^{\prime} \mathrm{FeNN}$ yields $\mathrm{Fe}-\mathrm{N}=1.902 \AA$ and $\mathrm{N}-\mathrm{N}=1.123 \AA$. This $\mathrm{N}-\mathrm{N}$ bond length is marginally longer than that in free $\mathrm{N}_{2}$ (1.098 $\AA$ ). Addition of the other iron atom clearly indicates a synergism between the $\mathrm{Fe}$ atoms in regards to activation of dinitrogen: B3LYP/CZDZ**++ geometry optimization of septet L'FeNNFeL'31 shows significant shortening of the $\mathrm{Fe}-\mathrm{N}$ bond $(\mathrm{Fe}-\mathrm{N}=1.80 \AA ; \Delta(\mathrm{Fe}-\mathrm{N})=-0.10 \AA)$ and lengthening of the $\mathrm{N}-\mathrm{N}$ bond $(\mathrm{N}-\mathrm{N}=1.19 \AA$; $\Delta(\mathrm{N}-\mathrm{N})=+0.06 \AA)$ versus $L^{\prime} F e N N$, Chart 1. Note that the optimized parameters for $\mathrm{L}^{\prime} \mathrm{FeNNFeL}$ ' agree well with the experimental $\mathrm{Fe}-\mathrm{N}$ and $\mathrm{N}-\mathrm{N}$ distances given in Table 1. Coordination of L'Fe to the terminal $\mathrm{N}$ of L'FeNN results in formation of in-phase and out-of-phase combinations between $\mathrm{Fe} \mathrm{d} \pi$ orbitals and the orbital depicted in Chart 1. This orbital overlap gives a greater infusion of electron density into the $\pi^{*}$ orbital of $\mathrm{N}_{2}$.

(30) Stoian, S.; Smith, J. M.; Holland, P. L.; Bominaar, E. L.; Münck, E., manuscript in preparation.

(31) It was not possible to obtain SCF convergence for ROB3LYP/CSDZ**++ calculations on L'FeNNFeL'. Hence, unrestricted DFT calculations were employed. The literature suggests that spin contamination is less significant in UDFT in relation to comparable unrestricted Hartree-Fock (UHF) wave functions (e.g. ref 38). Geometry optimizations on quartet L'FeNN utilizing UB3LYP and ROB3LYP methods with the same CSDZ**++ basis set show little difference in calculated metrics (ROB3LYP/UB3LYP), e.g., FeN $=1.902 \AA / 1.901 \AA ; \mathrm{NN}=1.123 \AA / 1.129 \AA ; \mathrm{FeN}_{\mathrm{L}}=1.990 \AA / 1.980 \AA$; bite angle $=96^{\circ} / 96^{\circ}$; the total spin expectation value $\left\langle\mathrm{S}^{2}\right\rangle$ is 3.934 versus the ideal value of 3.750 . 
Chart 1

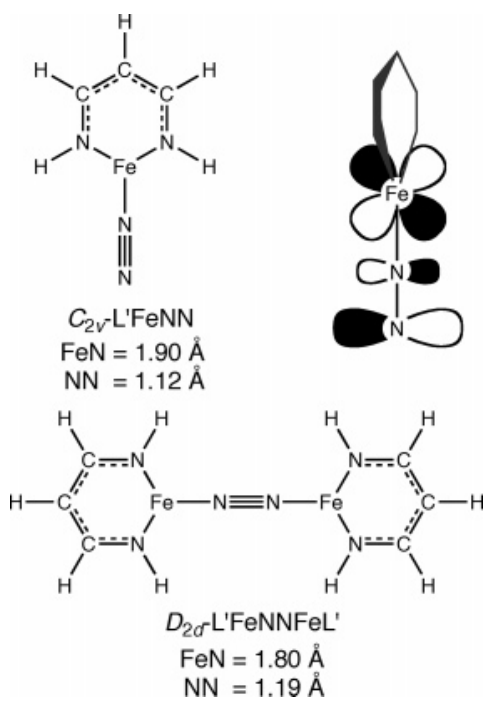

Scheme 2

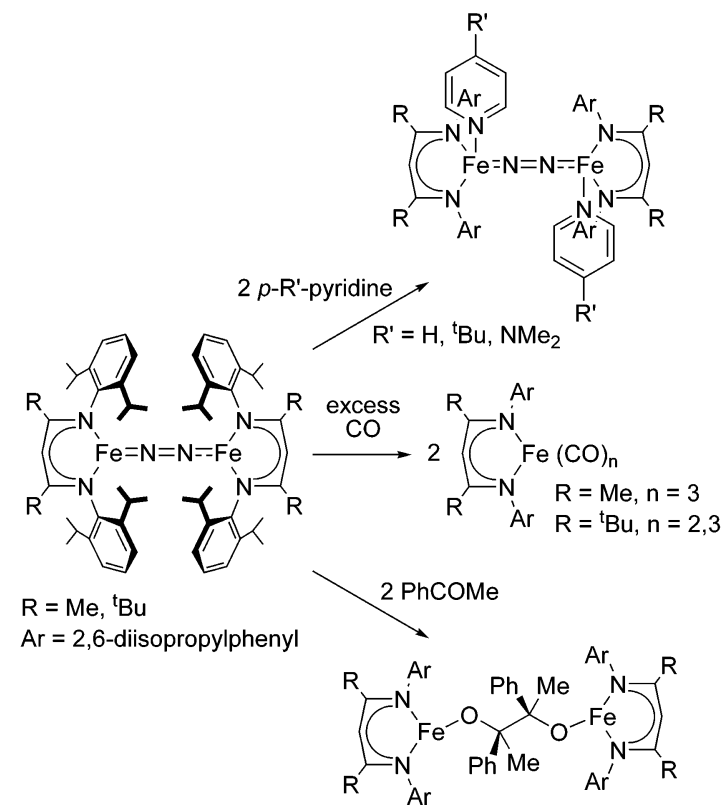

Four-Coordinate Iron- $\mathbf{N}_{2}$ Complexes. Treatment of $\mathrm{L}^{\mathrm{R}} \mathrm{FeNNFeL}{ }^{\mathrm{R}}$ with 2 molar equivalents of 4-tert-butylpyridine, 4-(dimethylamino)pyridine, or pyridine affords four-coordinate dinitrogen complexes of iron (Scheme 2). X-ray crystallographic analyses of the 4-tert-butylpyridine adducts, $\mathrm{L}^{\mathrm{R}} \mathrm{Fe}\left({ }^{t} \mathrm{Bupy}\right) \mathrm{NN}$ $\left({ }^{t} \mathrm{Bupy}\right) \mathrm{FeL}^{\mathrm{R}}$, are in the Supporting Information. The identification of the other pyridine adducts are based on the similarity of their ${ }^{1} \mathrm{H}$ NMR spectra to the structurally characterized ones. Each iron atom is four-coordinate, with a trigonal pyramidal geometry $(\tau=0.42-0.52)^{32}$ that is reminiscent of the four coordinate pyridine adducts of $\mathrm{L}^{t \mathrm{Bu}} \mathrm{FeH},{ }^{46} \mathrm{~L}^{t \mathrm{Bu}} \mathrm{FeF},{ }^{33}$ and $\mathrm{L}^{\mathrm{R}}$ $\mathrm{Fe}\left(\mathrm{NHR}^{\prime}\right){ }^{60 \mathrm{~b}}$

The crystal structures of these complexes show that the $\mathrm{N}-\mathrm{N}$ bonds are shortened by $\sim 0.03 \AA$ by the addition of a fourth

(32) We define $\tau$ as a normalized measure of trigonal distortion of a tetrahedral structure, with $\tau=0$ representing tetrahedral geometry and $\tau=1$ representing a trigonal pyramid in which the metal lies in the plane formed by the three basal ligands. For details, see ref 26.

(33) Vela, J.; Smith, J. M.; Yu, Y.; Ketterer, N. A.; Flaschenriem, C. J.; Lachicotte, R. J.; Holland, P. L. J. Am. Chem. Soc. 2005, 127, 78577870 . ligand to iron (Table 1). However, this difference is only slightly larger than the $3 \sigma$ threshold, and not much greater than the range seen in the two crystal structures of compound $\mathbf{1}$ above. ${ }^{34}$ Resonance Raman spectra of $\mathrm{L}^{\mathrm{Me}} \mathrm{Fe}\left({ }^{t} \mathrm{Bupy}\right) \mathrm{NN}\left({ }^{t} \mathrm{Bupy}\right) \mathrm{FeL}^{\mathrm{Me}}$ and its ${ }^{15} \mathrm{~N}_{2}$ isotopomer (Figure 4F,G) show an isotopically sensitive band at $1770 \mathrm{~cm}^{-1}$ that is assigned to the $\mathrm{N}-\mathrm{N}$ stretching vibration. Comparison to $\mathrm{L}^{\mathrm{Me}} \mathrm{FeNNFeL} \mathrm{Le}^{\mathrm{Me}}$ shows that the frequencies for $\mathrm{N}_{2}$ bound to four-coordinate iron and threecoordinate iron are similar, indicating a similar force constant for the $\mathrm{N}-\mathrm{N}$ bond (Table 1).

In the crystal structures of the $\mathrm{LFe}\left({ }^{t} \mathrm{Bupy}\right) \mathrm{NNFe}\left({ }^{t} \mathrm{Bupy}\right) \mathrm{FeL}$ complexes, there is a substantial angle between the two diketiminate planes $\left(52.22(5)^{\circ}\right.$ in the $\mathrm{L}^{\mathrm{Me}}$ complex and 82.50$(7)^{\circ}$ in the $\mathrm{L}^{t \mathrm{Bu}}$ complex). As a result of the twisting around the FeNNFe axis, there is no symmetry element in the diketiminate ligands: the two faces of the diketiminate differ in proximity to the nearby pyridine ligand, and the two sides of the diketiminate differ in proximity to the more distant pyridine ligand. However, the room temperature ${ }^{1} \mathrm{H}$ NMR spectra of $\mathrm{L}^{\mathrm{Me}} \mathrm{Fe}$ (py-R)NNFe(py-R)L ${ }^{\mathrm{Me}}$ (py-R $={ }_{4-}{ }^{t} \mathrm{BuC}_{5} \mathrm{H}_{4} \mathrm{~N}$ and $4-\mathrm{NMe}_{2}{ }^{-}$ $\mathrm{C}_{5} \mathrm{H}_{4} \mathrm{~N}$ ) in pentane- $d_{12}$ show two sets of peaks for the meta aryl, isopropyl methyl, and isopropyl methine protons and one set of peaks for $\alpha$-methyl, para aryl, and the backbone $\mathrm{C}-\mathrm{H}$ of the ligands. This suggests that at room temperature the two sides of the diketiminate are equivalent and the two faces are not. As the temperature was decreased to $-70{ }^{\circ} \mathrm{C}$, the singlets of the $\alpha$-methyl, para aryl, and one set of isopropyl methine and metaaryl protons broadened and then split into two peaks. The observed exchange process is consistent with rotation around the FeNNFe unit with a barrier of $9.5 \pm 0.2 \mathrm{kcal} / \mathrm{mol}$ for $\mathrm{L}^{\mathrm{Me}} \mathrm{Fe}\left({ }^{t} \mathrm{Bupy}\right) \mathrm{NNFe}\left({ }^{t} \mathrm{Bupy}\right) \mathrm{L}^{\mathrm{Me}}$ and $9.3 \pm 0.2 \mathrm{kcal} / \mathrm{mol}$ for $\mathrm{L}^{\mathrm{Me}} \mathrm{Fe}\left(\mathrm{Me}_{2} \mathrm{Npy}\right) \mathrm{NNFe}\left(\mathrm{Me}_{2} \mathrm{Npy}\right) \mathrm{L}^{\mathrm{Me}}$. Because the exchange process makes the two halves of the ligands equivalent but retains the inequivalence of the two faces, and because there is no measurable difference between the barriers for the different pyridine adducts, we conclude that neither pyridine nor $\mathrm{N}_{2}$ dissociates on the NMR time scale.

Reactions of the $\mathbf{N}_{\mathbf{2}}$ Complexes. In evaluating the reactivity of $\mathrm{L}^{\mathrm{R}} \mathrm{FeNNFeL}{ }^{\mathrm{R}}$, it is important to know whether the FeNNFe core is stable in solution. To test this possibility, resonance Raman spectra of a pentane solution of $\mathrm{L}^{t \mathrm{Bu}} \mathrm{FeNNFe} \mathrm{L}^{t \mathrm{Bu}}$ have been monitored under an atmosphere of ${ }^{15} \mathrm{~N}_{2}$. Very little incorporation of ${ }^{15} \mathrm{~N}$ is observed over several days at room temperature, suggesting that no rapid cleavage/recombination events occur. $\mathrm{L}^{\mathrm{Me}} \mathrm{FeNNFe}{ }^{\mathrm{Me}}$, on the other hand, incorporates added ${ }^{15} \mathrm{~N}_{2}$ gas in less than $2 \mathrm{~d}$ at $-78{ }^{\circ} \mathrm{C}$ in pentane, showing that the reduction of steric bulk makes the $\mathrm{N}_{2}$ ligand labile.

Consistent with this idea, $\mathrm{L}^{\mathrm{Me}} \mathrm{FeNNFeL}{ }^{\mathrm{Me}}$ reacts with benzene to displace the $\mathrm{N}_{2}$ ligand irreversibly (Scheme 3 ). The rate of this reaction in mixtures of deuterated benzene and cyclohexane is strongly dependent on the concentration of benzene, suggesting an associative mechanism for the reaction (see Supporting Information for details). The X-ray crystal structure of the product reveals that it is $\mathrm{L}^{\mathrm{Me}} \mathrm{Fe}\left(\eta^{6}-\mathrm{C}_{6} \mathrm{H}_{6}\right)$ (Figure 5). All benzene $\mathrm{C}-\mathrm{C}$ and $\mathrm{Fe}-\mathrm{C}$ bond distances are within $3 \sigma$ of the mean indicating a $\eta^{6}$-binding mode. At room temperature the ${ }^{1} \mathrm{H}$ NMR spectrum $\left(\mathrm{C}_{6} \mathrm{D}_{6}\right)$ shows broad signals. The rhombic

(34) Estimated standard deviations from automatic programs are generally underestimated: Stout, G. H.; Jensen, L. H. X-ray Structure Determination: A Practical Guide; Wiley: New York, 1989; pp 418-419. 


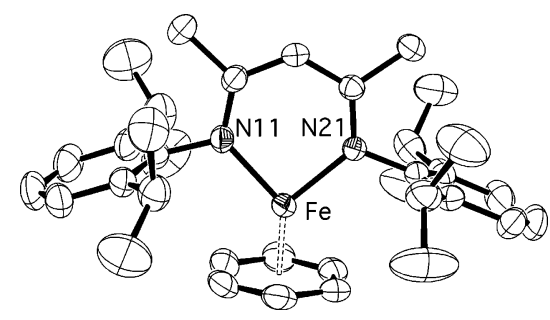

Figure 5. X-ray crystal structure of $\mathrm{L}^{\mathrm{Me}} \mathrm{Fe}\left(\mathrm{C}_{6} \mathrm{H}_{6}\right)$. Thermal ellipsoids shown at $50 \%$ probability, hydrogen atoms omitted for clarity. Bond lengths $(\AA)$ and angles $\left({ }^{\circ}\right): \mathrm{Fe}-\mathrm{N}(11) 1.966(1), \mathrm{Fe}-\mathrm{N}(21)$ 1.981(1), $\mathrm{Fe}-\mathrm{C} 2.143(2)$, $2.139(2), 2.151(2), 2.157(2), 2.144(2), 2.143(2) ; \mathrm{N}(11)-\mathrm{Fe}(1)-\mathrm{N}(21)$ 92.20(5).

Scheme 3

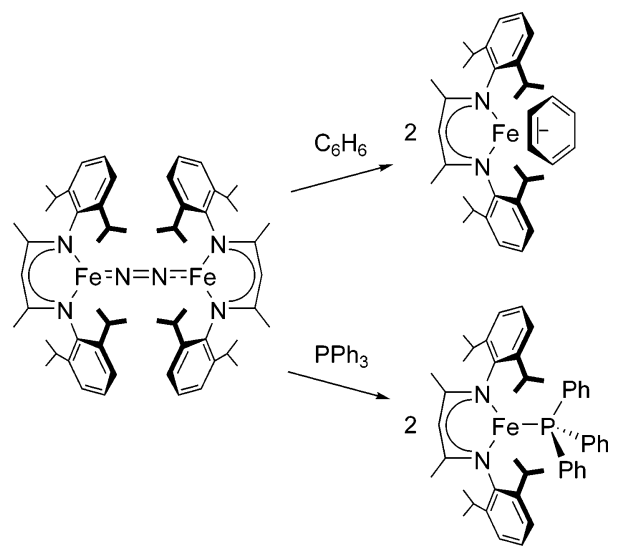

X-band EPR spectrum ( $g=2.20,2.01,1.98$; Figure 7c) and the solution magnetic moment $\left(\mu_{\mathrm{eff}}=2.5 \mu_{\mathrm{B}}\right)$ indicate an $S=$ $1 / 2$ ground state, so we formulate this compound as a low-spin iron(I) complex.

Reaction of $\mathrm{L}^{\mathrm{Me}} \mathrm{FeNNFeL}{ }^{\mathrm{Me}}$ with excess $\mathrm{CO}$ in diethyl ether affords a novel iron(I) complex, $\mathrm{L}^{\mathrm{Me}} \mathrm{Fe}(\mathrm{CO})_{3}$, as dark green crystals (Scheme 2). The X-ray crystal structure of this compound is shown in Figure 6a. The geometry around the iron center is square pyramidal, where one of the carbonyl groups is in the axial position of the square pyramid. The bond length of the axial $\mathrm{Fe}-\mathrm{C}$ bond $(\mathrm{Fe}-\mathrm{C}(14) 1.871(2) \AA)$ is slightly longer than the other two $\mathrm{Fe}-\mathrm{C}$ bonds $(\mathrm{Fe}-\mathrm{C}(13) 1.7957(16) \AA)$. The IR spectrum of $\mathrm{L}^{\mathrm{Me}} \mathrm{Fe}(\mathrm{CO})_{3}$ in pentane shows three bands (2042, $1971,1960 \mathrm{~cm}^{-1}$ ) in the carbonyl region. The magnetic moment is $2.0 \mu_{\mathrm{B}}$, and an axial X-band EPR signal (Figure 7) is observed at $77 \mathrm{~K}$ in frozen toluene, with $g_{\|}=1.99$ and $g_{\perp}=2.04$. Together, these measurements indicate that $\mathrm{L}^{\mathrm{Me}} \mathrm{Fe}(\mathrm{CO})_{3}$ has a low-spin $(S=1 / 2)$ electronic configuration at iron.

Reaction of $\mathrm{L}^{t \mathrm{Bu}} \mathrm{FeNNFe}{ }^{t \mathrm{Bu}}$ with excess $\mathrm{CO}$ gives a product with more complicated characteristics. Its crystal structure consists of a superposition of two complexes (Figure $6 \mathrm{~b}$ and Scheme 2): $\mathrm{L}^{t \mathrm{Bu}} \mathrm{Fe}(\mathrm{CO})_{3}$ and square-planar $\mathrm{L}^{t \mathrm{Bu}} \mathrm{Fe}(\mathrm{CO})_{2}$, which differ by the loss of the axial CO ligand. Consistent with a mixture of tricarbonyl and dicarbonyl species, the IR spectrum of this solid shows five bands at 2036, 2000, 1967, 1953, and $1922 \mathrm{~cm}^{-1}$. The $77 \mathrm{~K}$ X-band EPR spectrum contains an axial signal closely resembling that of $\mathrm{L}^{\mathrm{Me}} \mathrm{Fe}(\mathrm{CO})_{3}$ as well as a rhombic signal $(g=2.35,2.13,1.98)$ tentatively assigned to $\mathrm{L}^{t \mathrm{Bu}} \mathrm{Fe}(\mathrm{CO})_{2}$ (Figure 7). The EPR signature suggests that both carbonyl complexes have low-spin electronic configurations. Unfortunately, it has not yet been possible to separate these two complexes for more detailed characterization of the squareplanar iron(I) complex. (a)

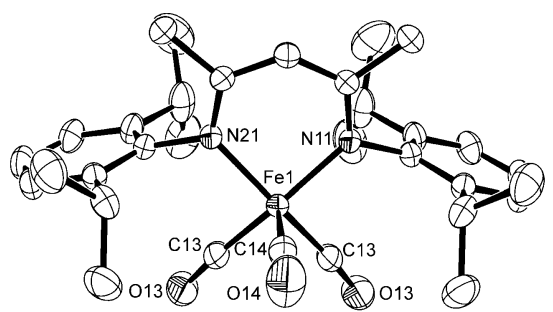

(b)

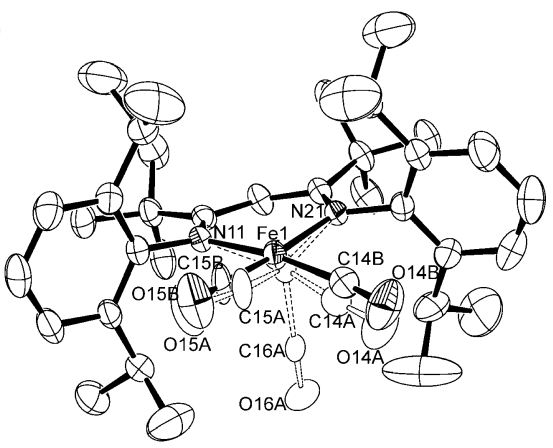

Figure 6. (a) X-ray crystal structure of $\mathrm{L}^{\mathrm{Me}} \mathrm{Fe}(\mathrm{CO})_{3}$. Thermal ellipsoids shown at 50\% probability, hydrogen atoms omitted for clarity. Selected bond lengths $(\AA)$ and angles $\left({ }^{\circ}\right)$ : $\mathrm{Fe}(1)-\mathrm{N}(11) 1.9827(11), \mathrm{Fe}(1)-\mathrm{C}(13)$ 1.7957(16), $\mathrm{Fe}(1)-\mathrm{C}(14)$ 1.871(2); $\mathrm{N}(11)-\mathrm{Fe}(1)-\mathrm{N}(11)^{\prime} 90.96(6), \mathrm{C}(13)-$ $\mathrm{Fe}(1)-\mathrm{N}(11)$ 90.66(6), $\mathrm{C}(13)-\mathrm{Fe}(1)-\mathrm{N}(11)^{\prime} 163.18(7), \mathrm{C}(14)-\mathrm{Fe}(1)-$ $\mathrm{N}(11)$ 98.83(6), C(13)-Fe(1)-C(13) 83.08(10), C(13)-Fe(1)-C(14) 97.45(8). (b) X-ray crystal structure of cocrystallized $\mathrm{L}^{t \mathrm{Bu}} \mathrm{Fe}(\mathrm{CO})_{2}(80 \%)$ and $\mathrm{L}^{t \mathrm{Bu}} \mathrm{Fe}(\mathrm{CO})_{3}(20 \%$, dashed lines). Thermal ellipsoids shown at $50 \%$ probability, hydrogen atoms omitted for clarity. Selected bond lengths $(\AA)$ and angles $\left({ }^{\circ}\right)$ for $\mathrm{L}^{t \mathrm{Bu}} \mathrm{Fe}(\mathrm{CO})_{2}: \mathrm{Fe}(1)-\mathrm{N}(11)$ 1.984(3), $\mathrm{Fe}(1)-\mathrm{N}(21)$ 1.947(3), $\mathrm{Fe}(1)-\mathrm{C}(14 \mathrm{~B})$ 1.791(7), $\mathrm{Fe}(1)-\mathrm{C}(15 \mathrm{~B}) 1.825(9)$; N(11)-Fe(1)$\mathrm{N}(21)$ 94.20(13), C(14B) $-\mathrm{Fe}(1)-\mathrm{N}(11)$ 168.3(3), C(14B) $-\mathrm{Fe}(1)-\mathrm{N}(21)$ 92.29(17), C(15B)-Fe(1)-N(11) 91.9(3), C(15B)-Fe(1)-N(21) 172.2(2), $\mathrm{C}(14 \mathrm{~B})-\mathrm{Fe}(1)-\mathrm{C}(15 \mathrm{~B}) 82.6(3)$.
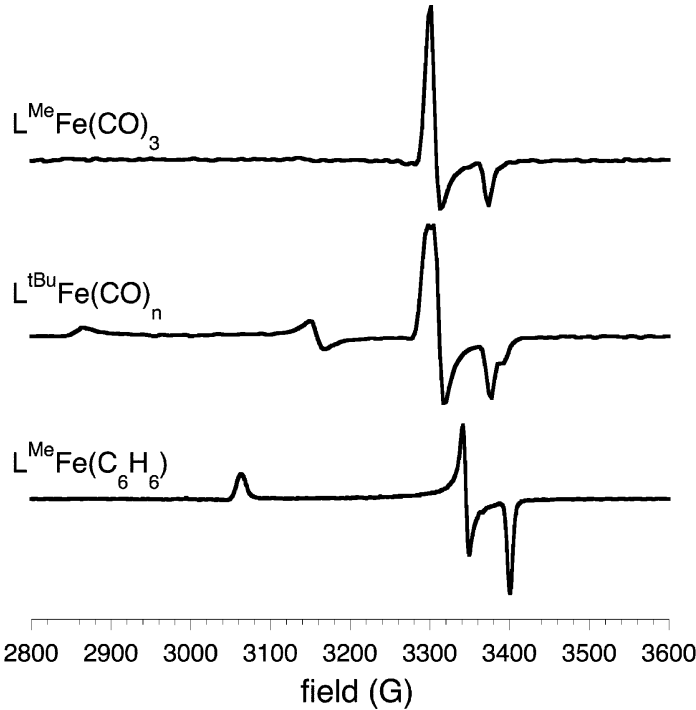

Figure 7. X-band EPR spectra of (a) $\mathrm{L}^{\mathrm{Me}} \mathrm{Fe}(\mathrm{CO})_{3}$; (b) a mixture of $\mathrm{L}^{t \mathrm{Bu}}$ $\mathrm{Fe}(\mathrm{CO})_{3}$ and $\mathrm{L}^{\mathrm{tBu}} \mathrm{Fe}(\mathrm{CO})_{2}$; (c) $\mathrm{L}^{\mathrm{Me}} \mathrm{Fe}\left(\mathrm{C}_{6} \mathrm{H}_{6}\right)$. Solvent: toluene; temperature $=77 \mathrm{~K}$; frequency $=9.42 \mathrm{GHz}$; power $=1.0 \mathrm{~mW}$; attenuation $=30 \mathrm{~dB}$.

Reaction of $\mathrm{L}^{\mathrm{Me}} \mathrm{FeNNFeL}{ }^{\mathrm{Me}}$ with 2 equiv of $\mathrm{PPh}_{3}$ results in the formation of dark purple $\mathrm{L}^{\mathrm{Me}} \mathrm{FePPh}_{3}$, as identified by X-ray crystallography (Figure 8) and ${ }^{1} \mathrm{H}$ NMR spectroscopy. Interestingly, in the crystal structure the phosphine ligand is bent out of the iron- $\beta$-diketiminate plane by $28.42(5)^{\circ}$, bringing the phosphorus atom 1.197(5) $\AA$ out of the plane. The origin of this bending is probably steric in nature. One of the phenyl rings of $\mathrm{PPh}_{3}$ is wedged between two isopropyl groups of the 


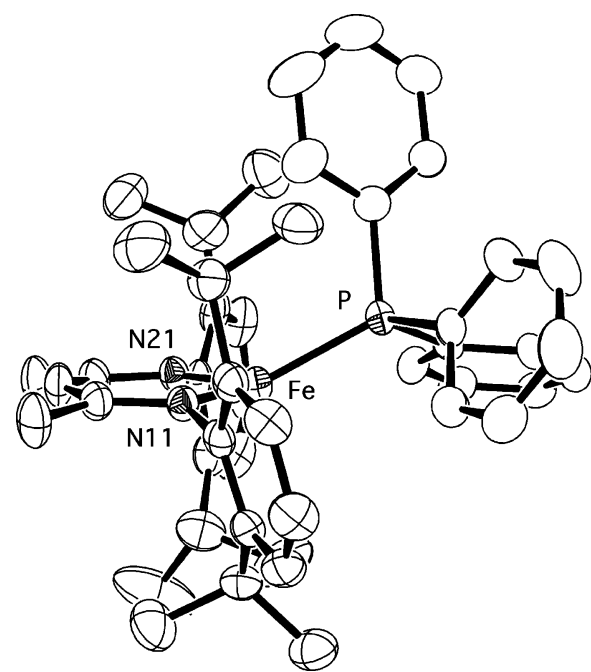

Figure 8. X-ray crystal structure of $\mathrm{L}^{\mathrm{Me}} \mathrm{FePPh}_{3}$. Thermal ellipsoids shown at 50\% probability, hydrogen atoms omitted for clarity. The phenyl groups of $\mathrm{PPh}_{3}$ are shown as solid white. Selected bond lengths ( $\mathrm{A}$ ) and angles $\left(^{\circ}\right): \mathrm{Fe}-\mathrm{P} 2.2348(8), \mathrm{Fe}-\mathrm{N} 11$ 1.953(2), $\mathrm{Fe}-\mathrm{N} 21$ 1.959(2); N11-Fe-N21 98.13(8), N11-Fe-P 127.25(6), N21-Fe-P 125.25(6).

$\beta$-diketiminate ligand, causing the $\beta$-diketiminate aryl rings to bend away from the phenyl ring so that the methine carbons of the isopropyl groups are 6.798(4) $\AA$ on one side but 4.166(4) $\AA$ on the other side. This asymmetry is evident in lowtemperature ${ }^{1} \mathrm{H}$ NMR spectra in pentane- $d_{12}$, but at higher temperature there is free rotation and averaged $C_{2 v}$ symmetry (see Supporting Information). The three-coordinate environment results in an $\mathrm{Fe}-\mathrm{P}$ bond length $(2.2348(8) \AA)$ that is shorter than the corresponding $\mathrm{Fe}-\mathrm{P}$ bond length (2.2889(9) $\AA$ ) in the four-coordinate iron(I) complex, $\left(\mathrm{PhB}\left(\mathrm{CH}_{2} \mathrm{PPh}_{2}\right)_{3}\right) \mathrm{FePPh}_{3} \cdot{ }^{35}$ Like its precursor dinitrogen complex, $\mathrm{L}^{\mathrm{Me}} \mathrm{FePP}_{3}$ is not stable in $\mathrm{C}_{6} \mathrm{D}_{6}$ solution. Unlike the carbonyl and benzene adducts, the $\mathrm{PPh}_{3}$ adduct is a high spin iron(I) complex as evidenced by the magnetic moment $\left(\mu_{\mathrm{eff}}=3.6 \mu_{\mathrm{B}}\right)$ and the absence of an X-band EPR signal at $77 \mathrm{~K}^{36}$

Addition of 2 molar equivalents of acetophenone to a dark red pentane solution of $\mathrm{L}^{\mathrm{Me}} \mathrm{FeNNFeL}{ }^{\mathrm{Me}}$ or $\mathrm{L}^{t \mathrm{Bu}} \mathrm{FeNNFe} \mathrm{L}^{t \mathrm{Bu}}$ at $-35{ }^{\circ} \mathrm{C}$ leads to yellow or orange solids characterized as $\left[\mathrm{L}^{\mathrm{R}} \mathrm{FeOC}(\mathrm{Me}) \mathrm{Ph}\right]_{2}$ (Scheme 2; crystal structures shown in Supporting Information). Interestingly, the molecule has the rac diastereomer of the pinacolate ligand. The loss of symmetry in the molecule caused by the formation of the chiral centers is reflected in the ${ }^{1} \mathrm{H}$ NMR spectrum of $\left[\mathrm{L}^{\mathrm{Me}} \mathrm{FeOC}(\mathrm{Me}) \mathrm{Ph}\right]_{2}$ (for example, four sets of isopropyl $\mathrm{CH}_{3}$ groups were observed). The ${ }^{1} \mathrm{H}$ NMR spectra exclude the presence of the meso diastereomer, which would show up to eight sets of isopropyl $\mathrm{CH}_{3}$ groups.

Reduction of $\mathbf{L}^{t \mathrm{Bu}} \mathrm{FeCl}$ in the Absence of $\mathbf{N}_{2}$. Treatment of solutions of $\mathrm{L}^{t \mathrm{Bu}} \mathrm{FeCl}$ with $\mathrm{KC}_{8}$ in diethyl ether or THF, under an atmosphere of argon, results in the formation of forest green solutions of a metastable compound assigned as $\mathrm{L}^{\mathrm{tBu}} \mathrm{Fe}(\mathrm{KCl})$ (solv) $)_{x}$ (Scheme 4). When argon is removed from $\mathrm{L}^{t \mathrm{Bu}} \mathrm{Fe}(\mathrm{KCl})$ $(\text { solv })_{x}$ under vacuum and nitrogen is introduced to the forest green solution, an instant color change from green to red-purple

(35) Brown, S. D.; Betley, T. A.; Peters, J. C. J. Am. Chem. Soc. 2003, 125, $322-323$

(36) We have characterized the related high-spin iron(I) compound $\mathrm{L}^{t \mathrm{Bu} F e}$ (HCCPh) using Mössbauer and EPR spectroscopy: Stoian, S. A.; Yu, Y.; Smith, J. M.; Holland, P. L.; Bominaar, E. L.; Münck, E. Inorg. Chem. 2005, 44, 4915-4922.

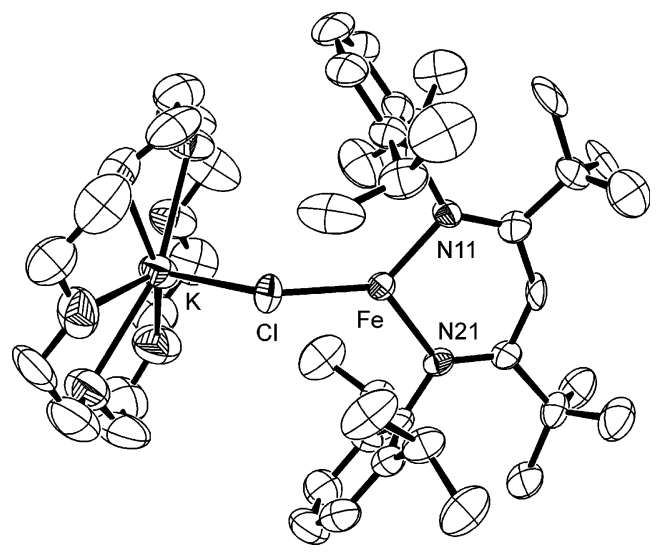

Figure 9. X-ray crystal structure of $\mathrm{L}^{\mathrm{tBu}} \mathrm{FeClK}(18$-crown-6). Thermal ellipsoids shown at 50\% probability. Hydrogen atoms, minor conformer of tert-butyl group, and toluene solvate omitted for clarity. Selected bond lengths $(\AA)$ and angles $\left({ }^{\circ}\right)$ : $\mathrm{Fe}-\mathrm{N} 11$ 1.934(6), $\mathrm{Fe}-\mathrm{Cl} 2.235(3), \mathrm{K}-\mathrm{O}$ $2.850(9), \quad 2.741(7), \quad 2.952(9), \quad 2.848(10), \quad 2.830(9), \quad 2.774(8), \quad \mathrm{K}-\mathrm{Cl}$ 3.074(3); $\mathrm{N} 11-\mathrm{Fe}-\mathrm{N} 21$ 101.8(3), N11- $\mathrm{Fe}-\mathrm{Cl} 134.3(2), \mathrm{N} 21-\mathrm{Fe}-\mathrm{Cl}$ 123.8(2), $\mathrm{Fe}-\mathrm{Cl}-\mathrm{K}$ 134.17(11).

\section{Scheme 4}

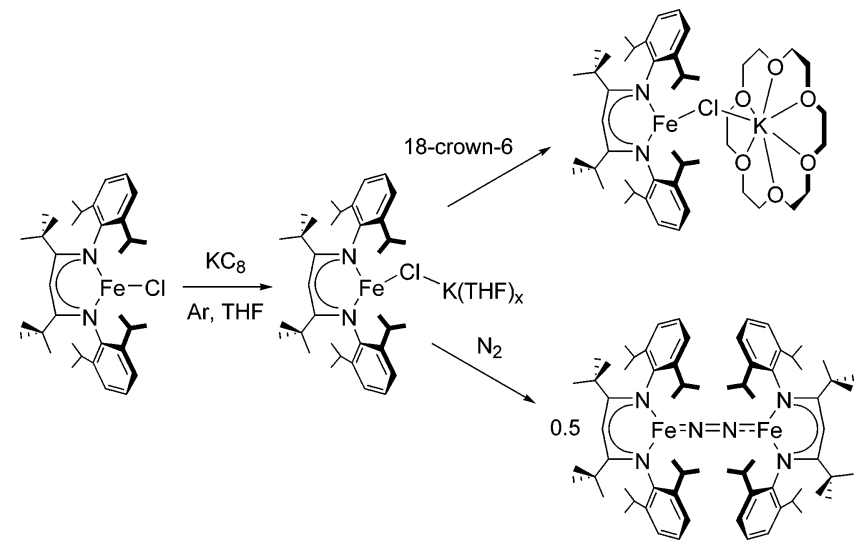

is observed and characteristic ${ }^{1} \mathrm{H}$ NMR resonances for $\mathrm{L}^{t \mathrm{Bu}} \mathrm{FeNNFeL^{t \textrm {Bu } }}$ appear. This confirms that transient iron(I) complexes are kinetically competent in the formation of the irondinitrogen complexes from $\mathrm{L}^{\mathrm{tBu}} \mathrm{FeCl}, \mathrm{KC}_{8}$, and $\mathrm{N}_{2}$.

The green intermediate species decomposes to an intractable orange mixture within a few hours. However, performing the reduction in the presence of 18 -crown- 6 affords dark green crystals as part of a mixture of products. The X-ray crystal structure of one product, $\mathrm{L}^{t \mathrm{Bu}} \mathrm{Fe}(\mathrm{KCl})(18$-crown-6) (Scheme 4), is shown in Figure 9. The $\mathrm{Fe}-\mathrm{Cl}-\mathrm{K}$ angle is $134.17(11)^{\circ}$, and the $\mathrm{Fe}-\mathrm{Cl}$ distance is $2.235(3) \AA$, compared with 2.172(1) $\AA$ in $\mathrm{L}^{t \mathrm{Bu}} \mathrm{FeCl}$. A solvent toluene molecule has a carbon roughly $3.6 \AA$ from the potassium atom, opposite the bridging chloride. However, disorder of the toluene limits the precision of the structure. This is a rare example of a complex with an alkali halide as a ligand; to our knowledge the only related iron complex is $\left[\left(\mathrm{Me}_{3} \mathrm{Si}\right)_{2} \mathrm{~N}\right]_{2} \mathrm{Fe}(\mu-\mathrm{Cl}) \mathrm{Li}(\mathrm{THF})_{3} \cdot{ }^{37}$

Two-Electron Reduction of $\mathrm{L}^{\mathrm{R}} \mathrm{FeNNFe} \mathrm{L}^{\mathrm{R}}$. Reduction of

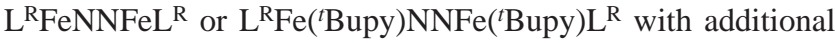
$\mathrm{KC}_{8}$ gives the dark blue-green complexes $\mathrm{K}_{2} \mathrm{~L}^{\mathrm{R}} \mathrm{FeNNFe} \mathrm{L}^{\mathrm{R}}$, isolated in low yield (Scheme 5). They are soluble in pentane, suggesting that the alkali metal remains tightly bound in solution.

(37) Siemeling, U.; Vorfeld, U.; Neumann, B.; Stammler, H.-G. Inorg. Chem. 2000, 39, 5159-5160. 


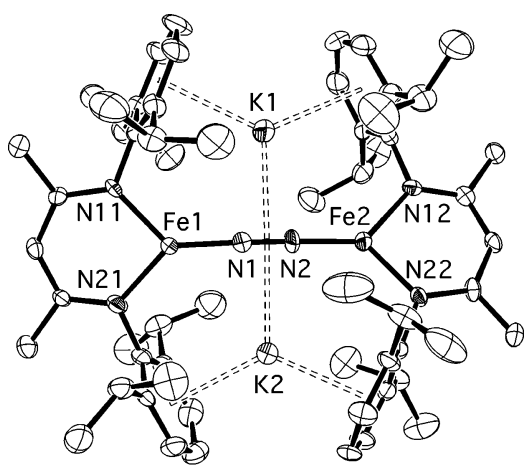

Figure 10. X-ray crystal structure of $\mathrm{K}_{2} \mathrm{~L}^{\mathrm{Me}} \mathrm{FeNNFeL}{ }^{\mathrm{Me}}$. Thermal ellipsoids shown at 50\% probability, hydrogen atoms omitted for clarity. Selected bond lengths $(\AA)$ and angles $\left({ }^{\circ}\right)$ : $\mathrm{Fe}(1)-\mathrm{N}(1)$ 1.741(5), $\mathrm{Fe}(1)-\mathrm{N}(11)$ 1.915(5), $\mathrm{Fe}(1)-\mathrm{N}(21)$ 1.936(5), $\mathrm{Fe}(2)-\mathrm{N}(2)$ 1.736(5), $\mathrm{Fe}(2)-\mathrm{N}(12)$ 1.931(5), $\quad \mathrm{Fe}(2)-\mathrm{N}(22) \quad 1.928(5), \quad \mathrm{N}(1)-\mathrm{N}(2) \quad 1.215(6), \quad \mathrm{K}(1)-\mathrm{N}(1)$ 2.778(6), $\mathrm{K}(1)-\mathrm{N}(2)$ 2.748(5), $\mathrm{K}(2)-\mathrm{N}(1) 2.800(6), \mathrm{K}(2)-\mathrm{N}(2) 2.796(5)$; $\mathrm{N}(11)-\mathrm{Fe}(1)-\mathrm{N}(21)$ 96.2(2), $\mathrm{N}(1)-\mathrm{Fe}(1)-\mathrm{N}(11)$ 131.3(2), $\mathrm{N}(1)-\mathrm{Fe}(1)-$ $\mathrm{N}(21) \quad 132.6(2), \quad \mathrm{N}(12)-\mathrm{Fe}(2)-\mathrm{N}(22) \quad 95.0(2), \quad \mathrm{N}(2)-\mathrm{Fe}(2)-\mathrm{N}(12)$ 133.6(2), $\mathrm{N}(2)-\mathrm{Fe}(2)-\mathrm{N}(22) 131.0(2)$.

Scheme 5

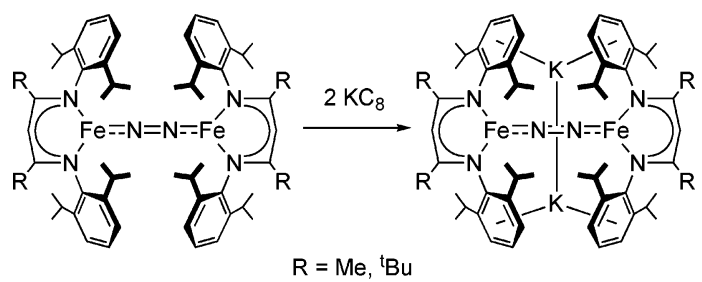

In solution, the $\mathrm{K}_{2} \mathrm{~L}^{\mathrm{R}} \mathrm{FeNNFeL^{ \textrm {R } }}$ complexes each adopt a $D_{2 d}$ or $D_{2 h}$ averaged structure, since again only seven signals are observed in ${ }^{1} \mathrm{H}$ NMR spectra.

The structure of $\mathrm{K}_{2} \mathrm{~L}^{\mathrm{Me}} \mathrm{FeNNFeL}{ }^{\mathrm{Me}}$, as determined by X-ray crystallography (Figure 10), is analogous to that of $\mathrm{M}_{2} \mathrm{~L}^{t \mathrm{Bu}}$ FeNNFeL $^{t \mathrm{Bu}}(\mathrm{M}=\mathrm{Na}, \mathrm{K}),{ }^{25}$ where the potassium atom coordinates to the bridging $\mathrm{N}_{2}$ and the aryl rings of the ligand. The $\mathrm{K}-\mathrm{N}$ bond lengths in $\mathrm{K}_{2} \mathrm{~L}^{\mathrm{Me}} \mathrm{FeNNFeL}{ }^{\mathrm{Me}}(2.748(5)-$ $2.800(6) \AA$ ) are slightly longer than those of $\mathrm{K}_{2} \mathrm{~L}^{t \mathrm{Bu}} \mathrm{FeNNFeL}{ }^{t \mathrm{Bu}}$ (2.690(6)-2.696(6) $\AA$ ). The $\mathrm{Fe}-\mathrm{N}$ bond lengths are similar to those in $\mathrm{L}^{\mathrm{R}} \mathrm{FeNNFeL}{ }^{\mathrm{R}}$. As in the $\mathrm{L}^{t \mathrm{Bu}}$-supported alkali metal complexes, the two iron-diketiminate ligand planes of $\mathrm{K}_{2} \mathrm{~L}^{\mathrm{Me}}$ $\mathrm{FeNNFeL}^{\mathrm{Me}}$ are canted at an angle of $34.4(2)^{\circ}$. Most interestingly, the $\mathrm{N}-\mathrm{N}$ bond is further lengthened beyond that in $\mathrm{L}^{\mathrm{R}} \mathrm{FeNNFeL}{ }^{\mathrm{R}}$, to distances of $1.215(6)\left(\mathrm{K}_{2} \mathrm{~L}^{\mathrm{Me}} \mathrm{FeNNFeL}^{\mathrm{Me}}\right)$, 1.238(4) $\left(\mathrm{Na}_{2} \mathrm{~L}^{t \mathrm{Bu}} \mathrm{FeNNFeL}{ }^{t \mathrm{Bu}}\right)$, and 1.241(7) $\left(\mathrm{K}_{2} \mathrm{~L}^{t \mathrm{Bu}} \mathrm{FeNNFeL}^{t \mathrm{Bu}}\right)$ $\AA$ (Table 1).

Resonance Raman spectra of the alkali metal complexes contain multiple bands with frequencies that are sensitive to isotopic substitution in the $\mathrm{N}_{2}$ (Figure $4 \mathrm{C}, \mathrm{D}$; Figure $4 \mathrm{E}$ shows the difference spectrum). Using $\mathrm{K}_{2} \mathrm{~L}^{t \mathrm{Bu}} \mathrm{FeNNFeL}{ }^{t \mathrm{Bu}}$ these bands appear at $1589(1536 / 1565)$ and $1123(1087) \mathrm{cm}^{-1}$, and using $\mathrm{K}_{2} \mathrm{~L}^{\mathrm{Me}} \mathrm{FeNNFeL}{ }^{\mathrm{Me}}$ they are at 1625 (1569) and 1427 (1389) $\mathrm{cm}^{-1}$ (numbers in parentheses for the ${ }^{15} \mathrm{~N}_{2}$ isotopomer). The observation of multiple isotope-sensitive bands (with isotope shifts smaller than expected for a diatomic oscillator) indicates that there are multiple Raman active vibrational modes in which the bridging nitrogen atoms have significant kinetic energy. We attribute this effect to coupling between $\mathrm{C}=\mathrm{N} / \mathrm{C}=\mathrm{C}$ bond stretches near $1500 \mathrm{~cm}^{-1}$ and the $\mathrm{N}-\mathrm{N}$ bond stretch. Although the absence of a localized $\mathrm{N}-\mathrm{N}$ stretching vibration hinders the precise quantification of $\mathrm{N}-\mathrm{N}$ bond weakening through

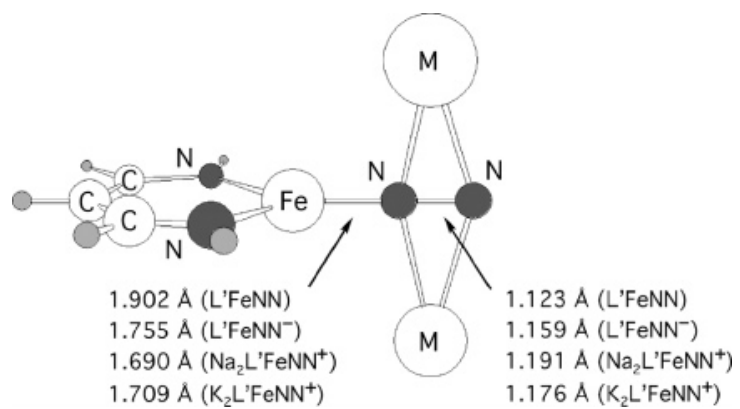

Figure 11. B3LYP/CZDZ**++ optimized geometries for quartet $\mathrm{L}^{*} \mathrm{FeNN}$, triplet $\mathrm{L}^{\prime} \mathrm{FeNN}{ }^{-}$, triplet $\mathrm{Na}_{2} \mathrm{~L}^{\prime} \mathrm{FeNN}{ }^{+}$, and triplet $\mathrm{K}_{2} \mathrm{~L}^{\prime} \mathrm{FeNN}{ }^{+}$.

vibrational spectroscopy, the $\mathrm{N}-\mathrm{N}$ frequencies are clearly lower in the $\left[\mathrm{L}^{\mathrm{R}} \mathrm{FeNNFeL}{ }^{\mathrm{R}}\right]^{2-}$ complexes than in their less reduced $\mathrm{L}^{\mathrm{R}} \mathrm{FeNNFeL^{ \textrm {R } }}$ counterparts (Table 1).

Computations: Role of Alkali Metals. All experimental attempts to remove the alkali metals from these complexes have led to decomposition or intractable products. Therefore, we turned to calculations to distinguish the effects of reduction from the effects of alkali metal coordination. The theoretical model complex L'FeNN was first reduced by a single electron and then pairs of alkali metal ions were ligated to the dinitrogen ligand. Thus, B3LYP/CSDZ**++ geometry optimizations of triplet $\left[\mathrm{L}^{\prime} \mathrm{FeNN}\right]^{-},\left\{\mathrm{Na}_{2}\left[\mathrm{~L}^{\prime} \mathrm{FeNN}\right]\right\}^{+}$and $\left\{\mathrm{K}_{2}\left[\mathrm{~L}^{\prime} \mathrm{FeNN}\right]\right\}^{+}$were performed under $C_{2 v}$ symmetry using RODFT methods. The optimized geometry of $\left\{\mathrm{Na}_{2}\left[\mathrm{~L}^{\prime} \mathrm{FeNN}\right]\right\}^{+}$is shown in Figure 11, and the geometry of the potassium analogue is similar. The calculated bond lengths for these species are $\mathrm{Fe}-\mathrm{N}=1.755 \AA$ $\left(\left[\mathrm{L}^{\prime} \mathrm{FeNN}\right]^{-}\right), 1.690 \AA\left(\left\{\mathrm{Na}_{2}\left[\mathrm{~L}^{\prime} \mathrm{FeNN}\right]\right\}^{+}\right)$, and $1.709 \AA\left(\left\{\mathrm{K}_{2}-\right.\right.$ $\left.\left.\left[\mathrm{L}^{\prime} \mathrm{FeNN}\right]\right\}^{+}\right)$, while the calculated $\mathrm{N}-\mathrm{N}$ bond lengths are 1.159 , 1.191 , and $1.176 \AA$, respectively, for these same complexes. These calculated values can be compared to $\mathrm{Fe}-\mathrm{N}=1.902 \AA$ and $\mathrm{N}-\mathrm{N}=1.123 \AA$ in $\mathrm{L}^{\prime} \mathrm{FeNN}$ (see above). Although the metrical parameters are not accurate due to the truncation of the model, two points are of particular interest in the context of $\mathrm{N}_{2}$ activation. First, comparison of the results for L'FeNN and $\left[\mathrm{L}^{\prime} \mathrm{FeNN}\right]^{-}$indicates that reduction of iron significantly weakens $\mathrm{N}_{2}(\Delta(\mathrm{N}-\mathrm{N})=+0.037 \AA)$. Second, coordination of alkali metal ions causes further dinitrogen stretching $(\Delta(\mathrm{N}-\mathrm{N})$ $\sim+0.02-0.03 \AA)$. Both effects are comparable in terms of their impact on the $\mathrm{N}-\mathrm{N}$ bonding.

Inspection of the Kohn-Sham orbitals ${ }^{38}$ suggests that reduction of LFeNN places additional electron density in an orbital with $\mathrm{Fe}-\mathrm{N} \pi$-bonding character and $\mathrm{N}-\mathrm{N} \pi$-antibonding character. Also, the anion shows greater mixing of $\mathrm{NN} \pi^{*}$ with the $\mathrm{Fe} \mathrm{d} \pi$ orbitals than the corresponding (virtual) orbital in $\mathrm{L}^{\prime} \mathrm{FeNN}$. We ascribe the greater orbital mixing to a better energy match between the $\mathrm{N}-\mathrm{N} \pi^{*}$ orbital and the Fe-based $\mathrm{d} \pi$ orbitals. Coordination of the alkali metal ions to $\mathrm{N}_{2}$ enhances these orbital interactions and yields further $\mathrm{N}_{2}$ weakening.

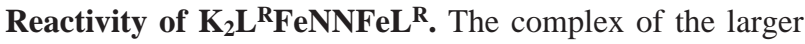
ligand, $\mathrm{K}_{2} \mathrm{~L}^{t \mathrm{Bu}} \mathrm{FeNNFeL}{ }^{t \mathrm{Bu}}$, is exceedingly sensitive, and upon standing it converts to $\mathrm{L}^{t \mathrm{Bu}} \mathrm{FeNNFeL}{ }^{t \mathrm{Bu}}$. We believe the major source of decomposition to be trace water on the surface of reaction vessels, as using silylated glassware somewhat reduces the amount of decomposition. The fragile nature of this complex and $\mathrm{Na}_{2} \mathrm{~L}^{t \mathrm{Bu}} \mathrm{FeNNFeL}{ }^{t \mathrm{Bu}}$ has precluded further studies of their

(38) Koch, W.; Holthausen, M. C. A Chemist's Guide to Density Functional Theory, Wiley-VCH: Weinheim, 2000. 
reactivities. $\mathrm{K}_{2} \mathrm{~L}^{\mathrm{Me}} \mathrm{FeNNFe} \mathrm{L}^{\mathrm{Me}}$ is slightly more robust. However, reactions with electrophiles give mixtures in which no product deriving from transformation of the $\mathrm{N}_{2}$ group is evident. Reaction with $\mathrm{CH}_{3} \mathrm{OTf}$ is cleaner, with quantitative formation of $\mathrm{L}^{\mathrm{Me}} \mathrm{FeCH}_{3}{ }^{28 \mathrm{a}}$ by ${ }^{1} \mathrm{H}$ NMR spectroscopy.

\section{Discussion}

Given the presence of iron in large-scale natural and industrial $\mathrm{N}_{2}$ fixation processes, it is surprising that until very recently all isolated complexes between iron and $\mathrm{N}_{2}$ had very little ground-state weakening of the $\mathrm{N}-\mathrm{N}$ bond, with $\mathrm{N}-\mathrm{N}$ distances less than $1.14 \AA$ and $\mathrm{N}-\mathrm{N}$ stretching frequencies greater than $1950 \mathrm{~cm}^{-1} .39$ As a result, synthetic iron-dinitrogen complexes were categorized as "unactivated." 40 However, the coordination number of iron in these complexes is five or greater. This contrasts with the iron atoms of the FeMoco, which are fourcoordinate in the isolated $\mathrm{M}^{\mathrm{N}}$ form, and may reach an even lower coordination number in the reduced, activated form. On the surface of metallic iron, the (111) face of iron is thought to be most active, and it is perhaps significant that this surface has the greatest number of highly exposed iron atoms. ${ }^{18}$ Our ability to make three- and four-coordinate complexes offers the opportunity to evaluate the effect of low coordination number of iron on coordinated $\mathrm{N}_{2}$.

Stretching of the $\mathrm{N}-\mathrm{N}$ Bond in Iron Dinitrogen Complexes. The extent of $\mathrm{N}_{2}$ reduction is much greater in $\mathrm{L}^{\mathrm{R}} \mathrm{FeNNFeL}{ }^{\mathrm{R}}$ than in five-coordinate complexes with an FeNNFe core (Table 1). The bond lengths $(1.18 \pm 0.01 \AA)$ and stretching frequencies $\left(1790 \pm 20 \mathrm{~cm}^{-1}\right)$ for the $\mathrm{NN}$ bonds are characteristic of a bond order between two $(\mathrm{MeN}=\mathrm{NMe} 1.25$ $\left.\AA ; 1575 \mathrm{~cm}^{-1}\right)^{41}$ and three $\left(\mathrm{N} \equiv \mathrm{N} 1.098 \AA ; 2331 \mathrm{~cm}^{-1}\right) .{ }^{1} \mathrm{In}$ other crystallographically characterized iron dinitrogen complexes, terminal $\mathrm{N}-\mathrm{N}$ bond lengths range from 1.07(1) $\AA-$ 1.14(1) $\AA,{ }^{39}$ while bridging $\mathrm{N}-\mathrm{N}$ have been observed at 1.13(2) $\AA .{ }^{42}$ Likewise, the N-N stretching frequencies of most other terminal iron dinitrogen complexes are also consistent with minimal activation of the $\mathrm{N}_{2}$ ligand $\left(\nu_{\mathrm{NN}}=1955-2112 \mathrm{~cm}^{-1}\right)$. The exceptions are the heterobimetallic bridging complexes $\mathrm{Fe}\left(\mathrm{PhBP}^{i \mathrm{Pr}}{ }_{3}\right)\left(\mathrm{N}_{2}\right) \mathrm{MgCl}(\text { ether })_{x}$ (ether $=\mathrm{THF}, x=2, v(\mathrm{NN})=$ $1830 \mathrm{~cm}^{-1}$; ether $=18$-crown-6, $\left.x=0.5, v_{\mathrm{NN}}=1884 \mathrm{~cm}^{-1}\right)^{24}$ and $\mathrm{Fe}\left[\left(\mathrm{N}_{3} \mathrm{~N}\right) \mathrm{Mo}-\mathrm{N}=\mathrm{N}\right]_{3}(d(\mathrm{NN})=1.20(3) \AA-1.27(2) \AA$, $\left.v_{\mathrm{NN}}=1703 \mathrm{~cm}^{-1}\right)^{43}$ complexes, where the iron atoms are also low coordinate.

The $\mathrm{N}-\mathrm{N}$ distances and $\mathrm{N}-\mathrm{N}$ stretching frequencies are similar between complexes of $\mathrm{L}^{\mathrm{Me}}$ and $\mathrm{L}^{t \mathrm{Bu}}$, indicating that the size of the $\beta$-diketiminate ligand plays little role in weakening the $\mathrm{N}-\mathrm{N}$ bond. Additionally, the long $\mathrm{N}-\mathrm{N}$ bond is reproduced in density-functional and multireference calculations on the truncated L'FeNNFeL', where all substituents are replaced by hydrogen. So, although the large ligands are essential for enforcing the low coordination number, they do not play a direct role in lengthening the $\mathrm{N}-\mathrm{N}$ bond.

(39) A full list of these complexes may be found in the Supporting Information. (40) Tuczek, F.; Lehnert, N. Angew. Chem., Int. Ed. 1998, 37, 2636-2638.

(41) Pearce, R. A. R.; Levin, I. W.; Harris, W. C. J. Chem. Phys. 1973, 59, 1209-1216.

(42) (a) Berke, H.; Bankhardt, W.; Huttner, G.; Von Seyerl, J.; Zsolnai, L. Chem. Ber. 1981, 114, 2754-2768. (b) Kandler, H.; Gauss, C.; Bidell, W.; Rosenberger, S.; Buergi, T.; Eremenko, I. L.; Veghini, D.; Orama, O.; Burger, P.; Berke, H. Chem. Eur. J. 1995, 1, 541-548.

(43) (a) O'Donoghue, M. B.; Zanetti, N. C.; Davis, W. M.; Schrock, R. R. J. Am. Chem. Soc. 1997, 119, 2753-2754. (b) O'Donoghue, M. B.; Davis, W. M.; Schrock, R. R.; Reiff, W. M. Inorg. Chem. 1999, 38, 243-252. (a)

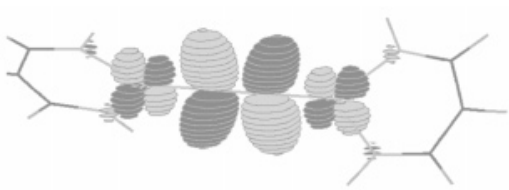

NOON

$0.42 \mathrm{e}^{-}$

(b)

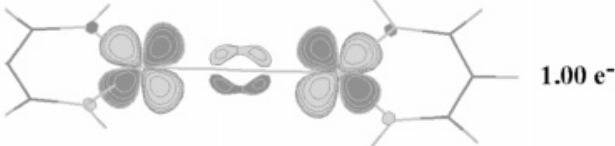

(c)

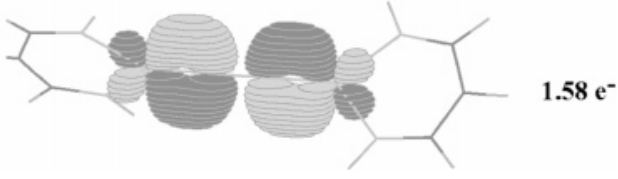

Figure 12. Key frontier orbitals from the MCSCF calculations on L'FeNNFeL'. Orbital (a) has $48 \% \mathrm{Fe}$ and $48 \% \mathrm{~N}$ character, (b) has $96 \% \mathrm{Fe}$ and $2 \% \mathrm{~N}$ character, and (c) has $60 \% \mathrm{Fe}$ and $35 \% \mathrm{~N}$ character. NOON $=$ natural orbital occupation number.

The effect of coordination number was evaluated through the use of 4-tert-butylpyridine, which coordinates to each iron atom to give trigonal pyramidal coordination. The frequencies of the $\mathrm{N}-\mathrm{N}$ stretching vibrations indicate similar extents of bond weakening between three- and four-coordinate complexes, and these are deemed more trustworthy than the minimal changes seen in $\mathrm{N}-\mathrm{N}$ distances (Table 1). Peters has recently reported four-coordinate iron- $\mathrm{N}_{2}$ complexes using a tris(phosphino)borate ligand, which give $\mathrm{N}-\mathrm{N}$ bonds with comparable lengths (e.g. 1.171(4) A) and frequencies (e.g., $\left.1884 \mathrm{~cm}^{-1}\right) .{ }^{24}$ Therefore, both three- and four-coordinate iron complexes are not substantially different from each other, but both give greater $\mathrm{N}-\mathrm{N}$ weakening than five- or six-coordinate complexes.

Computations and Electronic Structure. To tie these observations to specific orbital interactions, and to deconvolute the different contributions to $\mathrm{N}-\mathrm{N}$ bond weakening, MCSCF calculations were performed on L'FeNNFeL', where L' again represents a truncated $\beta$-diketiminate ligand. Multiconfiguration SCF computations of the type used here can offer a more accurate picture of electronic structure than DFT, but are often difficult to interpret as the natural orbitals derived from an MCSCF calculation are not limited to integral electron occupation numbers. ${ }^{44}$ In this research, the natural orbitals (i.e., those orbitals obtained through diagonalization of the first-order density matrix) are analyzed, and from these are obtained the natural orbital occupation numbers (NOONs). The NOONs range from 0 to $2 e^{-}$and give a measure of the multireference character. Schmidt and Gordon describe NOONs between 0.1 and 1.9 as indicative of "considerable multireference character. ${ }^{44}$

The key frontier orbitals (Figure 12) of L'FeNNFeL' have $\pi$-interactions between iron and nitrogen atoms, and are doubly degenerate because the diketiminate planes are perpendicular to one another. Figure $12 \mathrm{c}$ shows substantial population (NOON $=1.58 e^{-}$per member of the $E$ set) of a pair of natural MO's that have bonding interactions between $\mathrm{Fe}$ and the $\mathrm{N}$ of the bridging $\mathrm{N}_{2}$, and antibonding interactions between the two nitrogen atoms. This pair is strongly correlated with a pair of lower-occupation natural orbitals $\left(\mathrm{NOON}=0.42 e^{-}\right.$per member for this $E$ set) of higher energy (Figure 12a). Thus, the calculations indicate that in these $\beta$-diketiminate complexes,

(44) Schmidt, M. W.; Gordon, M. S. Annu. Rev. Phys. Chem. 1998, 49, 233266. 
$\pi$-back-bonding from iron into the $\mathrm{N}-\mathrm{N} \pi^{*}$ orbital is a major contributor to the weakened $\mathrm{N}-\mathrm{N}$ bond.

Evaluation of Potential Pathways to the $\mathbf{N}_{\mathbf{2}}$ Complexes. Reduction of an iron chloride complex to the dinitrogen complexes requires (a) reduction of iron and (b) replacement of $\mathrm{Cl}^{-}$with $\mathrm{N}_{2}$, but the order of these steps was unknown. We find that reduction of $\mathrm{L}^{t \mathrm{Bu}} \mathrm{FeCl}$ under $\mathrm{Ar}$ gives $\mathrm{L}^{t \mathrm{Bu}} \mathrm{FeCl}(\mathrm{K})$ (solvent $)_{x}$, which in turn reacts with $\mathrm{N}_{2}$ to give $\mathrm{L}^{t \mathrm{Bu}} \mathrm{FeNNFeL}{ }^{t \mathrm{Bu}}$. The latter reaction occurs more rapidly than reaction of $\mathrm{L}^{t \mathrm{Bu}} \mathrm{FeCl}$ with $\mathrm{KC}_{8}$ under $\mathrm{N}_{2}$. Therefore, the iron(I)- $\mathrm{KCl}$ complex is kinetically competent to be an intermediate during the reduction of $\mathrm{L}^{t \mathrm{Bu}} \mathrm{FeCl}$ under $\mathrm{N}_{2} \cdot{ }^{45}$

We have also observed that $\mathrm{L}^{t \mathrm{Bu}} \mathrm{FeNNFe} \mathrm{L}^{t \mathrm{Bu}}$ is formed by photolysis of the hydride complex $\left[\mathrm{L}^{t \mathrm{Bu}} \mathrm{FeH}\right]_{2}{ }^{46}$ in benzene solution with a high-pressure mercury lamp, and during attempted resonance Raman experiments on the same hydride complex. As pointed out by Fryzuk, the accomplishment of homogeneous catalytic $\mathrm{N}_{2}$ reduction is more feasible when strong reducing agents are not required to create the reduced metal center. ${ }^{47}$ Therefore, there is much current interest in polyhydride complexes that lead to dinitrogen complexes. Tyler has recently reported formation of an iron- $\mathrm{N}_{2}$ complex from dihydrogen reduction under $\mathrm{N}_{2}$. ${ }^{23 \mathrm{~b}}$

Two-Electron Reduction of the FeNNFe Core. Three complexes of the type (alkali) ${ }_{2} \mathrm{~L}^{\mathrm{R}} \mathrm{NNFeL} \mathrm{L}^{\mathrm{R}}$ have been characterized. Two alkali metal cations are trapped within the complex, bound to the $\mathrm{N}_{2}$ ligand and to the arene rings of the diketiminates. There is an increase in the $\mathrm{N}-\mathrm{N}$ distance $(0.03-0.05$ $\AA$ ). Resonance Raman spectra of these complexes give bands near $1600 \mathrm{~cm}^{-1}$ that are sensitive to ${ }^{15} \mathrm{~N}_{2}$ substitution in the bridging ligand. The $\mathrm{N}-\mathrm{N}$ bond lengthening and stretching frequency reduction lead to a self-consistent picture in which the $\mathrm{N}-\mathrm{N}$ bond is weakened by two-electron reduction.

According to the MCSCF description of L'FeNNFeL' presented above, two-electron reduction of L'FeNNFeL' unit places additional electron density (ca. $0.25 e^{-}$according to the NOONs) in the $\mathrm{MO}$ that is bonding between $\mathrm{Fe}$ and the $\mathrm{N}$ of bridging $\mathrm{N}_{2}$, and antibonding interactions between the two nitrogen atoms (Figure 12a). Therefore, reduction leads to greater population of the $\mathrm{N}_{2} \pi^{*}$ orbital. This model neatly accommodates the observation that reduction leads to greater $\mathrm{N}-\mathrm{N}$ weakening and a reduction in the magnetic moment.

DFT calculations on simplified L'FeNN models also show that alkali metal coordination causes a similar amount of stretching as reduction $(\sim 0.03 \AA)$. The stretching caused by side-on coordination of an alkali metal cation may seem unusual, because in the literature examples where $\mathrm{N}_{2}$ is bound side-on to alkali metals, there is minimal disruption of $\mathrm{N}-\mathrm{N}$ bonding. ${ }^{48,49}$ However, in combination with end-on binding to a transition metal (TM), alkali metal coordination increases polarization of the $\mathrm{TM}-\mathrm{N}_{2}$ unit, enhancing the effectiveness

(45) This contrasts with the nitrogen-free reduction of $\left[\mathrm{P}_{2} \mathrm{~N}_{2}\right] \mathrm{ZrCl}_{2}$ and $\left[\mathrm{P}_{2} \mathrm{~N}_{2}\right]$ $\mathrm{NbCl}\left(\mathrm{P}_{2} \mathrm{~N}_{2}=\mathrm{PhP}\left(\mathrm{CH}_{2} \mathrm{SiMe}_{2} \mathrm{NSiMe}_{2} \mathrm{CH}_{2}\right)_{2} \mathrm{PPh}\right)$, which leads to complexes that do not react with dinitrogen. See: Fryzuk, M. D.; Kozak, C. M.; Mehrkhodavandi, P.; Morello, L.; Patrick, B. O.; Rettig, S. J. J. Am. Chem. Soc. 2002, 124, 516-517.

(46) Smith, J. M.; Lachicotte, R. J.; Holland, P. L. J. Am. Chem. Soc. 2003, $125,15752-15753$

(47) Fryzuk, M. D.; Love, J. B.; Rettig, S. J.; Young, V. G. Science 1997, 275, $1445-1447$

(48) (a) Ho, J.; Drake, R. J.; Stephan, D. W. J. Am. Chem. Soc. 1993, 115 3792-3793. (b) Bazhenova, T. A.; Kulikov, A. V.; Shestakov, A. F.; Shilov, A. E.; Antipin, M. Y.; Lyssenko, K. A.; Struchkov, Y. T.; Makhaev, V. D. J. Am. Chem. Soc. 1995, 117, 12176-12180. of TM back-bonding into the coordinated $\mathrm{N}_{2} \cdot{ }^{50}$ It is perhaps relevant that small amounts of potassium are beneficial in the iron $(0)$ catalyst in the Haber-Bosch process, ${ }^{51}$ and that LEED experiments suggest that $\mathrm{N}_{2}$ bound to $\mathrm{Fe}(111)$ is not perpendicular to the surface, but is strongly inclined, ${ }^{52}$ suggesting a possible side-on binding mode.

The $\mathrm{N}-\mathrm{N}$ bond lengths (and less dramatically, the $\mathrm{Fe}-\mathrm{N}$ bond lengths) are dependent on the nature of the $\beta$-diketiminate ligand in the alkali metal containing complexes. In the less congested $\mathrm{K}_{2} \mathrm{~L}^{\mathrm{Me}} \mathrm{FeNNFeL}{ }^{\mathrm{Me}}$ complex, the $\mathrm{N}-\mathrm{N}$ bond length is only $\sim 0.03 \AA$ longer than in $\mathrm{L}^{\mathrm{Me}} \mathrm{FeNNFeL}{ }^{\mathrm{Me}}$, while in $\mathrm{K}_{2} \mathrm{~L}^{t \mathrm{Bu}} \mathrm{FeNNFeL}{ }^{t \mathrm{Bu}}$, the $\mathrm{N}-\mathrm{N}$ bond length increases by about $\sim 0.05 \AA$ from $\mathrm{L}^{t \mathrm{Bu}} \mathrm{FeNNFe} \mathrm{L}^{t \mathrm{Bu}}$. The $\mathrm{Fe}-\mathrm{N}$ bond lengths in $\mathrm{K}_{2} \mathrm{~L}^{\mathrm{Me}} \mathrm{FeNNFeL}{ }^{\mathrm{Me}}$ are also slightly shorter than in $\mathrm{K}_{2} \mathrm{~L}^{t \mathrm{Bu}} \mathrm{FeNNFeL}{ }^{t \mathrm{Bu}}$. The most likely reason is that the smaller binding pocket in $\mathrm{K}_{2} \mathrm{~L}^{t \mathrm{Bu}} \mathrm{FeNNFeL}{ }^{t \mathrm{Bu}}$ reduces the space for binding the alkali metals, and the only way to accommodate them is for the iron atoms to move away from each other. The greater apparent strain in $\mathrm{K}_{2} \mathrm{~L}^{t \mathrm{Bu}} \mathrm{FeNNFeL}{ }^{t \mathrm{Bu}}$ correlates with its lower stability (see below).

Reactivity of Reduced Iron $\boldsymbol{\beta}$-Diketiminate Dinitrogen Complexes. In general, $\mathrm{L}^{\mathrm{R}} \mathrm{FeNNFeL^{ \textrm {R } }}$ complexes react as lowcoordinate $\mathrm{Fe}(\mathrm{I})$ sources by loss of $\mathrm{N}_{2}$. Thus far, we have found $\mathrm{L}^{t \mathrm{Bu}} \mathrm{FeNNFeL}{ }^{t \mathrm{Bu}}$ to be less reactive than $\mathrm{L}^{\mathrm{Me}} \mathrm{FeNNFeL}{ }^{\mathrm{Me}}$, most likely due to greater protection of the $\mathrm{N}_{2}$ ligand. Thus, dissolving $\mathrm{L}^{\mathrm{Me}} \mathrm{FeNNFeL}{ }^{\mathrm{Me}}$ in benzene leads to quantitative formation of $\mathrm{L}^{\mathrm{Me}} \mathrm{Fe}\left(\eta^{6}-\mathrm{C}_{6} \mathrm{H}_{6}\right)$, but $\mathrm{L}^{t \mathrm{Bu}} \mathrm{FeNNFeL}{ }^{t \mathrm{Bu}}$ is stable in aromatic solvents at temperatures of up to $100{ }^{\circ} \mathrm{C}$. While reaction of $\mathrm{L}^{\mathrm{Me}} \mathrm{FeNNFeL}{ }^{\mathrm{Me}}$ with $\mathrm{PPh}_{3}$ to quantitatively form $\mathrm{L}^{\mathrm{Me}} \mathrm{Fe} \mathrm{PPh}_{3}$ is rapid at room temperature, $\mathrm{L}^{t \mathrm{Bu}} \mathrm{FeNNFeL}{ }^{t \mathrm{Bu}}$ reacts with $\mathrm{PPh}_{3}$ only at elevated temperatures, giving an intractable mixture of products.

These displacement reactions likely take place through an associative mechanism, a conclusion that is supported by (a) the dependence of the rate constant for reaction with benzene$d_{6}$ on $\left[\mathrm{C}_{6} \mathrm{D}_{6}\right]$, (b) the isolation of pyridine adducts of $\mathrm{L}^{\mathrm{Me}} \mathrm{FeNNFeL}{ }^{\mathrm{Me}}$, and (c) the aforementioned steric dependence of the substitution reactions. It is notable that the high-spin $\mathrm{N}_{2}$ complexes react with $\mathrm{CO}$ very rapidly to form the low-spin carbonyl complexes, indicating that the necessary spin flip accompanying ligand binding is very rapid.

Attempts to Functionalize Coordinated $\mathrm{N}_{2}$. The classical method of producing $\mathrm{NH}_{3}$ from an $\mathrm{N}_{2}$ complex is by adding

(49) However, lanthanides are capable of $\mathrm{N}-\mathrm{N}$ bond weakening. Representative examples: (a) Evans, W. J.; Ulibarri, T. A.; Ziller, J. W. J. Am. Chem. Soc. 1988, 110, 6877-6879. (b) Jubb, J.; Gambarotta, S. J. Am. Chem Soc. 1994, 116, 4477-4478. (c) Roussel, P.; Scott, P. J. Am. Chem. Soc. 1998, 120, 1070-1071. (d) Ganesan, M.; Gambarotta, S.; Yap, G. P. A. Angew. Chem., Int. Ed. Engl. 2001, 40, 766-769. (e) Cloke, F. G. N.; Hitchcock, P. B. J. Am. Chem. Soc. 2002, 124, 9352. (f) Evans, W. J.; Lee, D. S.; Lie, C.; Ziller, J. W. Angew. Chem., Int. Ed. 2004, 43, 55175519

(50) There are a few other synthetic complexes known with end-on binding to a late transition metal and side-on binding to an alkali metal: (a) Jonas, $\mathrm{K}$. Angew. Chem. 1973, 85, 1050. (b) Jonas, K.; Brauer, D. J.; Krüger, C. Roberts, P. J.; Tsay, Y. H. J. Am. Chem. Soc. 1976, 98, 74. (c) Klein, H. F.; Hammer, R.; Wenninger, J.; Friedrich, P.; Huttner, G. Z. Naturforsch. B. 1978, 33, 1267. (d) Jubb, J.; Gambarotta, S. J. Am. Chem. Soc. 1994, 116, 4477-4478. (e) Caselli, A.; Solari, E.; Scopelliti, R.; Floriani, C.; Re, N.; Rizzoli, C.; Chiesi-Villa, A. J. Am. Chem. Soc. 2000, 122, 36523670. (f) Bonomo, L.; Stern, C.; Solari, E.; Scopelliti, R.; Floriani, C. Angew. Chem., Int. Ed. Engl. 2001, 40, 1449-1452.

(51) Whitman, L. J.; Bartosch, C. E.; Ho, W.; Strasser, G.; Grunze, M. Phys Rev. Lett. 1986, 56, 1984-1987 and references therein.

(52) (a) Grunze, M.; Golze, M.; Hirschwald, W.; Freund, H. J.; Pulm, H.; Seip U.; Tsai, M. C.; Ertl, G.; Kueppers, J. Phys. Rev. Lett. 1984, 53, 850853. (b) Freund, H. J.; Bartos, B.; Messmer, R. P.; Grunze, M.; Kuhlenbeck, H.; Neumann, M. Surf. Sci. 1987, 185, 187-202. 
excess acid to release ammonia and/or hydrazine. ${ }^{53}$ Addition of $\mathrm{HCl}$, thiols, alcohols, or $\mathrm{H}\left(\mathrm{OEt}_{2}\right)_{2}{ }^{+} \mathrm{BAr}_{\mathrm{F}}{ }^{-54}$ to $\mathrm{Et}_{2} \mathrm{O}$ solutions of $\mathrm{L}^{t \mathrm{Bu}} \mathrm{FeNNFeL}{ }^{t \mathrm{Bu}}$ does not give detectable amounts $(<5 \%)$ of ammonia or hydrazine. However, acid addition protocols are harsh, and it has been observed that the products of protonation may also depend on the acid used, ${ }^{53}$ casting some doubt on the generality of this method as a means of characterization.

Bridging $\mathrm{N}_{2}$ complexes, particularly those of oxophilic early metal complexes, can react with aldehydes and ketones to give azines. ${ }^{55}$ However, treatment of $\mathrm{L}^{\mathrm{R}} \mathrm{FeNNFeL^{ \textrm {R } }}$ with acetophenone leads to the pinacol coupled complexes $\left[\mathrm{L}^{\mathrm{R}} \mathrm{FeOC}(\mathrm{Me})\right.$ $\mathrm{Ph}]_{2}$. Transition metal mediated pinacol coupling is typically the province of early transition metal complexes, ${ }^{56}$ making this an unusual transformation for an iron complex. The observation of pinacol coupling suggests that the formally iron(I) metal center acts as a one-electron reducing agent, forming a carbonbased radical that undergoes coupling to give the pinacolate ligand of the product. In another example of $\mathrm{L}^{\mathrm{Me}} \mathrm{FeNNFeL} \mathrm{L}^{\mathrm{Me}}$ acting as a reducing agent, it reacts with elemental sulfur to give the diiron(II) complex $\mathrm{L}^{\mathrm{Me}} \mathrm{FeSFeL}{ }^{\mathrm{Me}}{ }^{26}$

Peters and co-workers have recently shown that ironcoordinated dinitrogen $\mathrm{Fe}\left(\mathrm{PhBP}_{3} \mathrm{Pr}_{3}\right)\left(\mathrm{N}_{2}\right) \mathrm{MgCl}(\mathrm{THF})_{2}$ reacts with $\mathrm{CH}_{3}{ }^{+}$sources to give an iron complex of the methyldiazenido ligand. ${ }^{48}$ Theirs is the first well-characterized iron example of the electrophilic attack on coordinated nitrogen that has been long observed for dinitrogen complexes of early transition metals. ${ }^{\text {la }}$ Seeking to accomplish an analogous transformation, we treated the most reduced iron diketiminate dinitrogen complex, $\mathrm{K}_{2} \mathrm{~L}^{\mathrm{Me}} \mathrm{FeNNFeL}{ }^{\mathrm{Me}}$, with $\mathrm{CH}_{3} \mathrm{OTf}$. This reaction quantitatively results in the formation of $\mathrm{L}^{\mathrm{Me}} \mathrm{FeCH}_{3}$. Therefore, the doubly reduced diketiminate-iron-dinitrogen complexes act as sources of $\mathrm{Fe}(0)$, and $\mathrm{N}_{2}$ is again a leaving group. Efforts to create ligand geometries that are more conducive to $\mathrm{N}_{2}$ functionalization are underway.

\section{Conclusions}

Complexes in which $\mathrm{N}_{2}$ bridges multiple iron atoms are important models of potential intermediates in nitrogenase. The compounds reported here are promising initial models of FeNNFe intermediates that could result from binding $\mathrm{N}_{2}$ to lowcoordinate iron sites generated upon reduction of FeMoco. Using a combination of synthetic, structural, spectroscopic, and computational techniques, we have demonstrated that lowering coordination number at iron to three or four leads to exceptional weakening of a coordinated $\mathrm{N}_{2}$ ligand. In three-coordinate iron complexes, the fundamental orbital interaction involved is backbonding into the $\pi^{*}$ orbital of $\mathrm{N}_{2}$. Interestingly, the effect on back-bonding of lowering the coordination number is greater than that from lowering the oxidation state, demonstrating that the coordination geometry of the metal atom plays a dominant role in controlling the delocalization of electrons between the metal and ligands. In particular, the formally iron(I) fragment

(53) Leigh, G. J. Acc. Chem. Res. 1992, 25, 177-181.

(54) Brookhart, M.; Grant, B.; Volpe, A. F., Jr. Organometallics 1992, 11, 39203922 .

(55) (a) Turner, H. W.; Fellmann, J. D.; Rocklage, S. M.; Schrock, R. R.; Churchill, M. R.; Wasserman, H. J. J. Am. Chem. Soc. 1980, 102, 78097811. (b) Rocklage, S. M.; Turner, H. W.; Fellmann, J. D.; Schrock, R. R. Organometallics 1982, 1, 703-707. (c) Schrock, R. R.; Wesolek, M.; Liu, A. H.; Wallace, K. C.; Dewan, J. C. Inorg. Chem. 1988, 27, 2050-2054. (56) Wirth, T. Angew. Chem., Int. Ed. 1996, 35, 61-63.
(diketiminate)Fe is an exceptionally good $\pi$-donor because of the low-coordinate environment, in contrast to the usual assumption that low-coordinate complexes have predominantly electrophilic character.

The dinitrogen complexes are also competent synthetic precursors for low-coordinate iron(I) complexes through loss of $\mathrm{N}_{2}$. Attempted protonation and alkylation of $\mathrm{N}_{2}$ have led to attack at the metal or at the diketiminate ligand. Strategic ligand modification may lead to bridging $\mathrm{N}_{2}$ complexes with higher reactivity at coordinated $\mathrm{N}_{2}$.

\section{Experimental Section}

General Procedures. All manipulations were performed under a nitrogen atmosphere by standard Schlenk techniques or in an M. Braun glovebox maintained at or below $1 \mathrm{ppm}$ of $\mathrm{O}_{2}$ and $\mathrm{H}_{2} \mathrm{O}$. Glassware was dried at $150{ }^{\circ} \mathrm{C}$ overnight. ${ }^{1} \mathrm{H}$ NMR data were recorded on a Bruker Avance 400 spectrometer $(400 \mathrm{MHz})$ at $22{ }^{\circ} \mathrm{C}$. All peaks in the ${ }^{1} \mathrm{H}$ NMR spectra are referenced to residual protiated solvent. All peaks are singlets. In parentheses are listed: $T_{2}$ values in ms calculated as $\left(\pi \Delta v_{1 / 2}\right)^{-1},{ }^{7}$ integrations and assignments. In some cases, overlapping peaks prevented $T_{2}$ determinations. For certain complexes, not all signals could be assigned. IR spectra were recorded on a Mattson Instruments 6020 Galaxy Series FTIR using solution cells with CsF windows. UVvis spectra were measured on a Cary 50 spectrophotometer, using screwcap cuvettes, and are listed as: $\lambda$ in $\mathrm{nm}\left(\epsilon\right.$ in $\left.\mathrm{mM}^{-1} \mathrm{~cm}^{-1}\right)$. Solution magnetic susceptibilities were determined by the Evans method. ${ }^{58}$ Elemental analyses were determined by Desert Analytics, Tucson, AZ.

Pentane, diethyl ether $\left(\mathrm{Et}_{2} \mathrm{O}\right)$, and tetrahydrofuran (THF) were purified by passage through activated alumina and "deoxygenizer" columns from Glass Contour Co. (Laguna Beach, CA). Benzene, benzene- $d_{6}$, cyclohexane- $d_{12}$, and THF- $d_{8}$ were first dried over $\mathrm{CaH}_{2}$, then over $\mathrm{Na} /$ benzophenone, and then vacuum transferred into a storage container. Before use, an aliquot of each solvent was tested with a drop of sodium benzophenone ketyl in THF solution. Diatomaceous earth was dried overnight at $200{ }^{\circ} \mathrm{C}$ under vacuum. Triphenylphosphine was recrystallized from pentane at $-35{ }^{\circ} \mathrm{C}$, pyridines were dried over molecular sieves, and acetophenone was crystallized from pentane and stored in the dark at $-35^{\circ} \mathrm{C}$. The iron(II) $\beta$-diketiminate complexes $\mathrm{L}^{\mathrm{BB}} \mathrm{FeCl}^{59}$ and $\left[\mathrm{L}^{\mathrm{Me}} \mathrm{Fe}(\mu-\mathrm{Cl})\right]_{2}{ }^{60 \mathrm{~b}}$ were prepared by literature procedures. $\mathrm{KC}_{8}$ was prepared by heating potassium and graphite at $150{ }^{\circ} \mathrm{C}$ under an argon atmosphere. ${ }^{15} \mathrm{~N}_{2}$ (98\% isotopic purity) was obtained from Cambridge Isotopes, and ${ }^{15} \mathrm{~N}$-labeled compounds were handled under an atmosphere of argon. Photolysis experiments used a $200 \mathrm{~W} \mathrm{Hg} / \mathrm{Xe}$ lamp.

$\mathbf{L}^{\mathrm{Me}} \mathbf{F e N N F e L}{ }^{\mathrm{Me}}$ (1). A yellow slurry of $\mathrm{L}^{\mathrm{Me}} \mathrm{Fe}(\mu-\mathrm{Cl})_{2} \mathrm{Li}(\mathrm{THF})_{2}{ }^{60 \mathrm{a}}$ $(2.28 \mathrm{~g}, 3.27 \mathrm{mmol})$ in toluene $(40 \mathrm{~mL})$ was stirred at $80^{\circ} \mathrm{C}$ overnight. The toluene was removed under reduced pressure, and pentane $(60 \mathrm{~mL})$ and $\mathrm{KC}_{8}(530 \mathrm{mg}, 3.92 \mathrm{mmol})$ were added to the resultant orange solid. The reaction mixture was stirred overnight at room temperature, and it slowly turned red with the formation of black graphite. After settling for $2 \mathrm{~h}$, the supernatant was filtered through diatomaceous earth to give a dark red solution. The solution was concentrated to ca. $10 \mathrm{~mL}$ and stored at $-35{ }^{\circ} \mathrm{C}$. A very dark red solid was obtained in three crops $(1.10 \mathrm{~g}, 69 \%) . \mathrm{L}^{\mathrm{Me}} \mathrm{Fe}^{15} \mathrm{~N}^{15} \mathrm{NFeL}^{\mathrm{Me}}$ was synthesized in a similar fashion under an atmosphere of ${ }^{15} \mathrm{~N}_{2}$ gas and handled under Ar. ${ }^{1} \mathrm{H}$ NMR $\left(\mathrm{C}_{6} \mathrm{D}_{12}\right) \delta 53\left(12 \mathrm{H}, 0.6, \mathrm{CH}_{3}\right),-19\left(24 \mathrm{H}, 2, \mathrm{CH}\left(\mathrm{CH}_{3}\right)_{2}\right),-20$ $(8 \mathrm{H}, 2, m-\mathrm{H}),-98(4 \mathrm{H}, 2, p-\mathrm{H}),-112\left(24 \mathrm{H}, 0.8, \mathrm{CH}\left(\mathrm{CH}_{3}\right)_{2}\right),-123$ $\left(8 \mathrm{H}, 2, \mathrm{CH}\left(\mathrm{CH}_{3}\right)_{2}\right),-280(2 \mathrm{H}, \mathrm{C}-H) . \mu_{\mathrm{eff}}\left(\right.$ Evans, $\left.\mathrm{C}_{6} \mathrm{D}_{12}\right) 7.9(3) \mu_{\mathrm{eff}}$ Anal. Calcd for $\mathrm{C}_{58} \mathrm{H}_{82} \mathrm{~N}_{6} \mathrm{Fe}_{2} \cdot \mathrm{C}_{5} \mathrm{H}_{12}$ : C 72.26, H 9.04, N 8.03. Found

(57) Ming, L.-J. In Physical Methods in Bioinorganic Chemistry; Que, L., Jr., Ed.; University Science Books: Sausalito, 2000; pp 375-464. (58) Baker, M. V.; Field, L. D.; Hambley, T. W. Inorg. Chem. 1988, 27, 7.

(59) Smith, J. M.; Lachicotte, R. J.; Holland, P. L. Organometallics 2002, 21 , 4808. 
C, 72.17 H, 8.71, N 8.07. UV-vis (pentane): 911 (9.1), 499 (20). The crystals used for the $\mathrm{X}$-ray crystal structures were grown from pentane at $-35{ }^{\circ} \mathrm{C}$ (1a) or ambient temperature (1b).

$\mathbf{L}^{t \mathrm{Bu}} \mathrm{FeNNFeL}^{t \mathrm{Bu}}$ (2). $\mathrm{KC}_{8}(532 \mathrm{mg}, 3.94 \mathrm{mmol})$ was added in portions to a red slurry of $\mathrm{L}^{\mathrm{tBu}} \mathrm{FeCl}^{59}(2.0 \mathrm{~g}, 3.37 \mathrm{mmol})$ in $\mathrm{Et}_{2} \mathrm{O}$ (40 $\mathrm{mL}$ ). There was immediate formation of black graphite and a very dark red solution. Occasionally, the solution was observed to become deep green, and changed to dark red within a few minutes. The mixture was stirred overnight at room temperature, and the solvent removed in vacuo. The residue was extracted with pentane and filtered through diatomaceous earth to give a red-purple solution. The solution was concentrated $(20 \mathrm{~mL})$ and placed in the freezer to give a very dark red-purple solid in two crops $(1.29 \mathrm{~g}, 70 \%) . \mathrm{L}^{t B u} \mathrm{Fe}^{15} \mathrm{~N}^{15} \mathrm{NFeL}^{t \mathrm{Bu}}$ was synthesized similarly under an atmosphere of ${ }^{15} \mathrm{~N}_{2}$ gas and handled under Ar. ${ }^{1} \mathrm{H}$ NMR $\left(\mathrm{C}_{6} \mathrm{D}_{6}\right) \delta 165(2 \mathrm{H}, 0.4$, backbone $\mathrm{C}-\mathrm{H}), 62\left(36 \mathrm{H}, 0.8, \mathrm{C}\left(\mathrm{CH}_{3}\right)_{3}\right)$, $-2(8 \mathrm{H}, 3, m-\mathrm{H}),-22\left(24 \mathrm{H}, 2, \mathrm{CH}\left(\mathrm{CH}_{3}\right)_{2}\right),-81\left(8 \mathrm{H}, 0.1, \mathrm{CH}\left(\mathrm{CH}_{3}\right)_{2}\right)$, $-97\left(24 \mathrm{H}, 0.4, \mathrm{CH}\left(\mathrm{CH}_{3}\right)_{2}\right),-120(4 \mathrm{H}, 2, p-\mathrm{H}) . \mu_{\mathrm{eff}}\left(\right.$ Evans, $\left.\mathrm{C}_{6} \mathrm{D}_{6}\right)$

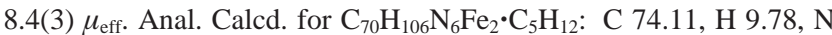
6.91. Found C 73.58, H 9.95, N 6.79. UV-vis (pentane): 941 (4.2), 520 (12), 384 (24).

$\mathbf{L}^{\mathrm{Me}} \mathbf{F e}\left({ }^{t}{ }^{\mathrm{Bupy}}\right) \mathbf{N N}\left({ }^{t} \mathbf{B u p y}\right) \mathbf{F e} \mathbf{L}^{\mathrm{Me}}(\mathbf{3})$. A $20 \mathrm{~mL}$ scintillation vial was charged with $\mathrm{L}^{\mathrm{Me}} \mathrm{FeNNFeL}{ }^{\mathrm{Me}}(100 \mathrm{mg}, 103 \mu \mathrm{mol})$ and pentane $(6 \mathrm{~mL})$ to give a red-purple solution. 4-tert-Butylpyridine ( $30 \mu \mathrm{L}, 206 \mu \mathrm{mol}$ ) was added via syringe, immediately giving a dark blue solution. After stirring at room temperature for $30 \mathrm{~min}$, the solution was concentrated to $2 \mathrm{~mL}$ and cooled to $-35^{\circ} \mathrm{C}$ using vapor diffusion with hexamethyldisiloxane. This gave dark blue crystals (100 mg, 78\%). The complex is soluble in pentane and $\mathrm{Et}_{2} \mathrm{O}$. The ${ }^{15} \mathrm{~N}$ labeled analogue of $\mathbf{3}$ was synthesized using $\mathrm{L}^{\mathrm{Me}} \mathrm{Fe}^{15} \mathrm{~N}^{15} \mathrm{NFeL}{ }^{\mathrm{Me}}$ and 4-tert-butylpyridine. ${ }^{1} \mathrm{H} \mathrm{NMR}$ $\left(\mathrm{C}_{6} \mathrm{D}_{12}\right) \delta 45\left(4 \mathrm{H}, 0.7, o-\mathrm{C}_{5} \mathrm{H}_{4} \mathrm{NC}\left(\mathrm{CH}_{3}\right)_{3}\right), 25(4 \mathrm{H}, 1, m-\mathrm{H}), 23(4 \mathrm{H}, 1$, $m-\mathrm{H}), 22\left(4 \mathrm{H}, m-\mathrm{C}_{5} \mathrm{H}_{4} \mathrm{NC}\left(\mathrm{CH}_{3}\right)_{3}\right), 7\left(24 \mathrm{H}, 0.8, \mathrm{CH}\left(\mathrm{CH}_{3}\right)_{2}\right), 1(24 \mathrm{H}, 5$, $\left.\mathrm{CH}\left(\mathrm{CH}_{3}\right)_{2}\right),-1\left(4 \mathrm{H}, 0.7, \mathrm{CH}\left(\mathrm{CH}_{3}\right)_{2}\right),-5\left(18 \mathrm{H}, 2, \mathrm{C}_{5} \mathrm{H}_{4} \mathrm{NC}\left(\mathrm{CH}_{3}\right)_{3}\right)$, $-8\left(4 \mathrm{H}, 0.6, \mathrm{CH}\left(\mathrm{CH}_{3}\right)_{2}\right),-39(4 \mathrm{H}, 1, p-\mathrm{H}),-112(2 \mathrm{H}, 0.2$, backbone C- $H$ ),$-162\left(12 \mathrm{H}, 0.3, \mathrm{CH}_{3}\right) . \mu_{\text {eff }}$ (Evans, $\left.\mathrm{C}_{6} \mathrm{D}_{12}\right) 5.9(3) \mu_{\text {eff. }}$ Anal. Calcd. for $\mathrm{C}_{76} \mathrm{H}_{108} \mathrm{~N}_{8} \mathrm{Fe}_{2}$ : C 73.29, H 8.74, N 8.99. Found C 73.10, H 8.51, N 8.74. UV-vis (pentane): 912 (11), 688 (12), 586 (16)

$\mathbf{L}^{t^{\mathrm{Bu}}} \mathbf{F e}\left({ }^{t} \mathbf{B u p y}\right) \mathbf{N N}\left({ }^{t} \mathbf{B u p y}\right) \mathbf{F e} \mathbf{L}^{t \mathbf{B u}}$ (4). A $20 \mathrm{~mL}$ scintillation vial was charged with $\mathrm{L}^{t \mathrm{Bu}} \mathrm{FeNNFeL}{ }^{t \mathrm{Bu}}(150 \mathrm{mg}, 131 \mu \mathrm{mol})$ and $\mathrm{Et}_{2} \mathrm{O}(8 \mathrm{~mL})$ to give a red-purple solution. 4-tert-Butylpyridine ( $40 \mu \mathrm{L}, 270 \mu \mathrm{mol})$ was added via syringe to form a dark green solution. After stirring at room temperature for $30 \mathrm{~min}$, the solvent was removed in vacuo. The residue was redissolved in warm pentane $(4 \mathrm{~mL})$ and cooled to -35 ${ }^{\circ} \mathrm{C}$ to give dark green crystals grown in two crops $(169 \mathrm{mg}, 91 \%) .{ }^{1} \mathrm{H}$ NMR $\left(\mathrm{C}_{6} \mathrm{D}_{6}\right) \delta 51(4 \mathrm{H}, 0.6, p-\mathrm{H}), 3.5\left(18 \mathrm{H}, 4, \mathrm{C}_{5} \mathrm{H}_{4} \mathrm{NC}\left(\mathrm{CH}_{3}\right)_{3}\right), 3.7$ $\left(24 \mathrm{H}, \mathrm{CH}\left(\mathrm{CH}_{3}\right)_{2}\right),\left(4 \mathrm{H}, o-\mathrm{C}_{5} \mathrm{H}_{4} \mathrm{NC}\left(\mathrm{CH}_{3}\right)_{3}\right), 1\left(12 \mathrm{H}, 4, \mathrm{CH}\left(\mathrm{CH}_{3}\right)_{2}\right), 0.9$ $\left(12 \mathrm{H}, 5, \mathrm{CH}\left(\mathrm{CH}_{3}\right)_{2}\right),-2\left(18 \mathrm{H}, 2, \mathrm{CH}\left(\mathrm{CH}_{3}\right)_{3}\right),-5\left(4 \mathrm{H}, 0.8, \mathrm{CH}\left(\mathrm{CH}_{3}\right)_{2}\right)$, $-49(8 \mathrm{H}, m-\mathrm{H}),\left(4 \mathrm{H}, m-\mathrm{C}_{5} \mathrm{H}_{4} \mathrm{NC}\left(\mathrm{CH}_{3}\right)_{3}\right),-68\left(4 \mathrm{H}, 0.4, \mathrm{CH}\left(\mathrm{CH}_{3}\right)_{2}\right)$, $-268\left(2 \mathrm{H}, 0.3\right.$, backbone C- $H$ ). $\mu_{\text {eff }}$ (Evans, $\left.\mathrm{C}_{6} \mathrm{D}_{6}\right) 8.5(3) \mu_{\text {eff. }}$ Anal. Calcd for $\mathrm{C}_{88} \mathrm{H}_{132} \mathrm{~N}_{8} \mathrm{Fe}_{2}$ : C 74.76, H 9.41, N 7.92. Found C 74.57, $\mathrm{H}$ 9.48, N 6.78. UV-vis (pentane): 953 (7.5), 630 (2.2), 560 (2.5) 486 (4.0), 424 (7.5).

$\mathrm{L}^{\mathrm{Me}} \mathbf{F e}\left(\mathrm{Me}_{2} \mathrm{Npy}\right) \mathbf{N N}\left(\mathrm{Me}_{2} \mathrm{Npy}\right) \mathrm{FeL}^{\mathrm{Me}}(\mathbf{5})$. Similarly to the preparation of 3, $\mathrm{L}^{\mathrm{Me}} \mathrm{FeNNFeL}{ }^{\mathrm{Me}}(100 \mathrm{mg}, 103 \mu \mathrm{mol})$ was treated with 4-(dimethylamino)pyridine $(25.2 \mathrm{mg}, 206 \mu \mathrm{mol})$ in $\mathrm{Et}_{2} \mathrm{O}(6 \mathrm{~mL})$ to afford 5 as dark blue crystals from pentane at $-35{ }^{\circ} \mathrm{C}(86 \mathrm{mg}, 69 \%) .{ }^{1} \mathrm{H}$ NMR $\left(\mathrm{C}_{6} \mathrm{D}_{12}\right) \delta \quad 45 \quad\left(4 \mathrm{H}, \quad 0.5, o-\mathrm{N}\left(\mathrm{CH}_{3}\right)_{2} \mathrm{C}_{5} \mathrm{H}_{4} \mathrm{~N}\right), 27 \quad(4 \mathrm{H}, \quad 0.5$, $\left.m-\mathrm{N}\left(\mathrm{CH}_{3}\right)_{2} \mathrm{C}_{5} \mathrm{H}_{4} \mathrm{~N}\right), 23(4 \mathrm{H}, 0.9, m-\mathrm{H}), 21(4 \mathrm{H}, 0.9, m-\mathrm{H}), 7(24 \mathrm{H}, 0.6$, $\left.\mathrm{CH}\left(\mathrm{CH}_{3}\right)_{2}\right), 0.9\left(24 \mathrm{H}, \mathrm{CH}\left(\mathrm{CH}_{3}\right)_{2}\right),-2\left(4 \mathrm{H}, 0.6, \mathrm{CH}\left(\mathrm{CH}_{3}\right)_{2}\right),-10(4 \mathrm{H}$, $\left.0.4, \mathrm{CH}\left(\mathrm{CH}_{3}\right)_{2}\right),-15\left(12 \mathrm{H}, 1, \mathrm{~N}\left(\mathrm{CH}_{3}\right)_{2} \mathrm{C}_{5} \mathrm{H}_{4} \mathrm{~N}\right),-39(4 \mathrm{H}, 0.9, p-\mathrm{H})$, $-115(2 \mathrm{H}, 0.2$, backbone $\mathrm{C}-\mathrm{H}),-177\left(12 \mathrm{H}, 0.3, \mathrm{CH}_{3}\right)$. UV-vis (pentane): 908 (6.6), 616 (11.5), 428 (0.2).

$\mathrm{L}^{t \mathrm{Bu}} \mathbf{F e}\left(\mathrm{Me}_{2} \mathrm{Npy}\right) \mathrm{NN}\left(\mathrm{Me}_{2} \mathrm{Npy}\right) \mathrm{FeL}^{t \mathrm{Bu}}(6)$. Similarly to the preparation of $4, \mathrm{~L}^{t \mathrm{Bu}} \mathrm{FeNNFeL}{ }^{t \mathrm{Bu}}(102 \mathrm{mg}, 89 \mu \mathrm{mol})$ was reacted with 4-(dimethylamino)pyridine (22 mg, $180 \mu \mathrm{mol})$ in $\mathrm{Et}_{2} \mathrm{O}(8 \mathrm{~mL})$. Dark green crystals were obtained from pentane at $-35{ }^{\circ} \mathrm{C}(98 \mathrm{mg}, 79 \%) .{ }^{1} \mathrm{H}$ NMR $\left(\mathrm{C}_{6} \mathrm{D}_{6}\right) \delta 116(2 \mathrm{H}, 0.2$, backbone $\mathrm{C}-H), 62(8 \mathrm{H}, 2, m-\mathrm{H}), 22(4 \mathrm{H}, 3$,
$p-\mathrm{H}), 15\left(4 \mathrm{H}, \mathrm{CH}\left(\mathrm{CH}_{3}\right)_{2}\right), 14\left(12 \mathrm{H}, \mathrm{N}\left(\mathrm{CH}_{3}\right)_{2} \mathrm{C}_{5} \mathrm{H}_{4} \mathrm{~N}\right),\left(4 \mathrm{H}, m-\mathrm{N}\left(\mathrm{CH}_{3}\right)_{2}-\right.$ $\left.\mathrm{C}_{5} \mathrm{H}_{4} \mathrm{~N}\right), 6\left(24 \mathrm{H}, 3, \mathrm{CH}\left(\mathrm{CH}_{3}\right)_{2}\right),-4\left(36 \mathrm{H}, 3, \mathrm{C}\left(\mathrm{CH}_{3}\right)_{3}\right),-10(4 \mathrm{H}$, $\left.\mathrm{CH}\left(\mathrm{CH}_{3}\right)_{2}\right),-24\left(24 \mathrm{H}, 0.7, \mathrm{CH}\left(\mathrm{CH}_{3}\right)_{2}\right),-69\left(4 \mathrm{H}, 2, o-\mathrm{N}\left(\mathrm{CH}_{3}\right)_{2} \mathrm{C}_{5} \mathrm{H}_{4} \mathrm{~N}\right)$. UV-vis (pentane): 717 (4.1), 613 (5.4), 430 (14), 385 (23).

$\mathbf{L}^{\mathrm{Me}} \mathbf{F e}(\mathbf{P y}) \mathbf{N N}(\mathbf{P y}) \mathbf{F e} \mathbf{L}^{\text {Me }}$ (7). Similarly to the preparation of $\mathbf{3}$, $\mathrm{L}^{\mathrm{Me}} \mathrm{FeNNFeL}{ }^{\mathrm{Me}}(86 \mathrm{mg}, 88 \mu \mathrm{mol})$ was reacted with pyridine $(15 \mu \mathrm{L}$, $185 \mu \mathrm{mol})$ in $\mathrm{Et}_{2} \mathrm{O}(6 \mathrm{~mL})$ to afford 7 as dark blue crystals from pentane at $-35{ }^{\circ} \mathrm{C}(76 \mathrm{mg}, 76 \%) .{ }^{1} \mathrm{H}$ NMR $\left(\mathrm{C}_{6} \mathrm{D}_{12}\right) \delta 135\left(2 \mathrm{H}, 0.6, p-\mathrm{C}_{5} \mathrm{H}_{4} \mathrm{~N}\right)$, $45\left(4 \mathrm{H}, 0.5, o-\mathrm{C}_{5} \mathrm{H}_{4} \mathrm{~N}\right), 25\left(4 \mathrm{H}, m-\mathrm{C}_{5} \mathrm{H}_{4} \mathrm{~N}\right),(4 \mathrm{H}, m-\mathrm{H}), 22(4 \mathrm{H}, 0.8$, $m-\mathrm{H}), 7\left(24 \mathrm{H}, 0.6, \mathrm{CH}\left(\mathrm{CH}_{3}\right)_{2}\right), 0.9\left(24 \mathrm{H}, \mathrm{CH}\left(\mathrm{CH}_{3}\right)_{2}\right),-1(4 \mathrm{H}, 0.6$, $\left.\mathrm{CH}\left(\mathrm{CH}_{3}\right)_{2}\right),-8\left(4 \mathrm{H}, 0.5, \mathrm{CH}\left(\mathrm{CH}_{3}\right)_{2}\right),-39(4 \mathrm{H}, 0.9, p-\mathrm{H}),-118(2 \mathrm{H}$, 0.2 , backbone $\mathrm{C}-\mathrm{H}),-166\left(12 \mathrm{H}, 0.3, \mathrm{CH}_{3}\right)$. UV-vis (pentane): 913 (7.2), 720 (6.6), 583 (8.3).

$\mathbf{L}^{\mathbf{M e}} \mathbf{F e}\left(\boldsymbol{\eta}^{6}-\mathbf{C}_{6} \mathbf{H}_{6}\right)(\mathbf{8})$. A $20 \mathrm{~mL}$ scintillation vial was charged with $\mathrm{L}^{\mathrm{Me}} \mathrm{FeNNFeL}{ }^{\mathrm{Me}}(100 \mathrm{mg}, 103 \mu \mathrm{mol})$ and pentane $(6 \mathrm{~mL})$ to give a dark red solution. Benzene $(0.5 \mathrm{~mL})$ was added, and the solution was stirred at room temperature overnight. The solution was pumped down $(2 \mathrm{~mL})$, and the residue was dissolved in hexamethyldisiloxane $(2 \mathrm{~mL})$ and cooled to $-35^{\circ} \mathrm{C}$ to give dark red crystals (86 mg, 76\%). ${ }^{1} \mathrm{H}$ NMR $\left(\mathrm{C}_{5} \mathrm{D}_{12},-60{ }^{\circ} \mathrm{C}\right) \delta 118(2 \mathrm{H}, 0.2, p-\mathrm{H}), 11\left(12 \mathrm{H}, 1, \mathrm{CH}\left(\mathrm{CH}_{3}\right)_{2}\right),-28$ $\left(12 \mathrm{H}, 0.1, \mathrm{CH}\left(\mathrm{CH}_{3}\right)_{2}\right),-42\left(6 \mathrm{H}, 0.4, \mathrm{CH}_{3}\right),-57(4 \mathrm{H}, 0.6, m-\mathrm{H}),-158$ $(1 \mathrm{H}, 0.5$, backbone $\mathrm{C}-\mathrm{H}),-205\left(4 \mathrm{H}, 0.1, \mathrm{CH}\left(\mathrm{CH}_{3}\right)_{2}\right) . \mu_{\text {eff }}\left(\right.$ Evans, $\left.\mathrm{C}_{6} \mathrm{D}_{12}\right)$ $2.5 \mu_{\text {B. }}$. Anal. Calcd for $\mathrm{C}_{35} \mathrm{H}_{47} \mathrm{~N}_{2} \mathrm{Fe}$ : C 76.21, H 8.59, N 5.08. Found C 76.29, H 8.01, N 5.28. UV-vis (pentane): 917 (0.4), 496 (1.3).

$\mathbf{L}^{\mathbf{M e}} \mathbf{F e}\left(\mathbf{P P h}_{3}\right)$ (9). A $20 \mathrm{~mL}$ scintillation vial was charged with $\mathrm{L}^{\mathrm{Me}} \mathrm{FeNNFeL}{ }^{\mathrm{Me}}(100 \mathrm{mg}, 103 \mu \mathrm{mol})$ and pentane $(6 \mathrm{~mL})$ to give a dark red solution. A solution of $\mathrm{PPh}_{3}(54 \mathrm{mg}, 206 \mu \mathrm{mol})$ in pentane (2 $\mathrm{mL}$ ) was added to give a dark purple solution. The solution was stirred at room temperature for $30 \mathrm{~min}$, and the solvent was pumped down (2 $\mathrm{mL})$. The residue was redissolved in hexamethyldisiloxane $(2 \mathrm{~mL})$ and cooled to $-35^{\circ} \mathrm{C}$ to give two crops of dark purple crystals $(110 \mathrm{mg}$, $72 \%) . \mathrm{L}^{\mathrm{Me}} \mathrm{Fe}\left(\mathrm{PPh}_{3}\right)$ is soluble in pentane and $\mathrm{Et}_{2} \mathrm{O}$, reacts with aromatic solvents, and is thermally unstable in solution. ${ }^{1} \mathrm{H}$ NMR $\left(\mathrm{C}_{6} \mathrm{D}_{12}\right) \delta 56$ $(1 \mathrm{H}, 0.7$, backbone $\mathrm{C}-\mathrm{H}), 37(4 \mathrm{H}, 2, m-\mathrm{H}), 8\left(12 \mathrm{H}, 2, \mathrm{CH}\left(\mathrm{CH}_{3}\right)_{2}\right), 7$ $(6 \mathrm{H}, 3, m-\mathrm{Ph}), 5(3 \mathrm{H}, 3, p-\mathrm{Ph}), 0.2(6 \mathrm{H}, o-\mathrm{Ph})-14(12 \mathrm{H}, 0.9, \mathrm{CH}-$ $\left.\left(\mathrm{CH}_{3}\right)_{2}\right),-24(2 \mathrm{H}, 2, p-\mathrm{H}),-29\left(2 \mathrm{H}, 0.3, \mathrm{CH}\left(\mathrm{CH}_{3}\right)_{2}\right),-100(2 \mathrm{H}, 0.8$ $\left.\mathrm{CH}\left(\mathrm{CH}_{3}\right)_{2}\right),-122\left(6 \mathrm{H}, 1, \mathrm{CH}_{3}\right) . \mu_{\text {eff }}$ (Evans, $\left.\mathrm{C}_{6} \mathrm{D}_{12}\right) 3.6(3) \mu_{\text {eff. }}$ Anal. Calcd for $\mathrm{C}_{47} \mathrm{H}_{56} \mathrm{~N}_{2} \mathrm{FeP}: \mathrm{C} 76.72, \mathrm{H} 7.67, \mathrm{~N} 3.80$. Found $\mathrm{C} 75.40, \mathrm{H}$ 7.59, N 3.98. UV-vis (pentane): 583 (2.2).

$\mathrm{L}^{\mathrm{Me}} \mathrm{Fe}(\mathrm{CO})_{3}$ (10). A resealable flask was charged with $\mathrm{L}^{\mathrm{Me}} \mathrm{FeNNFeL}{ }^{\mathrm{Me}}(100 \mathrm{mg}, 103 \mu \mathrm{mol})$ and $\mathrm{Et}_{2} \mathrm{O}(5 \mathrm{~mL})$ to give a dark red solution. The flask was connected to a vacuum line, and the solution frozen at $-196{ }^{\circ} \mathrm{C}$. The headspace was evacuated, and the solution thawed. The flask was backfilled with $\mathrm{CO}$ to approximately $1 \mathrm{~atm}$, leading to the immediate formation of a dark green solution. The solution was stirred for $30 \mathrm{~min}$ at room temperature and the volatile materials were removed in vacuo. The residue was extracted with pentane and filtered through diatomaceous earth. The solution was concentrated to $4 \mathrm{~mL}$ and cooled to $-35^{\circ} \mathrm{C}$ to give dark green crystals $(67 \mathrm{mg}, 58 \%) . \mu_{\text {eff }}$ (Evans, $\left.\mathrm{C}_{6} \mathrm{D}_{6}\right) 2.0 \mu_{\mathrm{B}}$. IR $\left(\mathrm{C}_{5} \mathrm{H}_{12}\right) v_{\mathrm{CO}} 2042,1971$, 1960. Anal. Calcd. for $\mathrm{C}_{32} \mathrm{H}_{41} \mathrm{~N}_{2} \mathrm{O}_{3} \mathrm{Fe}$ : C 68.94, H 7.41, N 5.02. Found C 69.89, H 7.14, N 5.08. UV-vis (pentane): 642 (0.94), 422 (1.7), $502(1.1)$

$\mathbf{L}^{t \mathrm{Bu}} \mathbf{F e}(\mathbf{C O})_{n}$ (11). Similarly to the preparation of $\mathbf{1 0}, \mathrm{L}^{t \mathrm{Bu}} \mathrm{FeNNFe} \mathrm{L}^{\mathrm{tBu}}$ (100 mg, $87 \mu \mathrm{mol})$ in $\mathrm{Et}_{2} \mathrm{O}(5 \mathrm{~mL})$ was treated with $\mathrm{CO}$. Brown-green crystals of the mixture 11 were obtained from pentane at $-35^{\circ} \mathrm{C}$. IR $\left(\mathrm{C}_{5} \mathrm{H}_{12}\right) v_{\mathrm{CO}} 2036,2000,1967,1953,1922 \mathrm{~cm}^{-1}$.

$\mathbf{L}^{\text {MeFeOC(Me)(Ph)C(Me)(Ph)COFeL }}{ }^{\text {Me }}$ (12). A $20 \mathrm{~mL}$ scintillation vial was charged with $\mathrm{L}^{\mathrm{Me}} \mathrm{FeNNFe} \mathrm{L}^{\mathrm{Me}}(100 \mathrm{mg}, 103 \mu \mathrm{mol})$ and pentane $(8 \mathrm{~mL})$ to give a dark red solution. The solution was cooled at $-35^{\circ} \mathrm{C}$ for $30 \mathrm{~min}$, and then acetophenone $(25 \mathrm{mg}, 205 \mu \mathrm{mol})$ in pentane (1 $\mathrm{mL}$ ) was added to give a dark green solution. The reaction was warmed to room temperature and stirred overnight to give a dark yellow solution, with the precipitation of a yellow solid. The volatile materials were removed under reduced pressure, and the residue washed with hexamethyldisiloxane $(1 \mathrm{~mL})$ to remove dark colored impurities. The 
remaining yellow solid was redissolved in $\mathrm{Et}_{2} \mathrm{O}$ and filtered through diatomaceous earth. The solution was concentrated to $4 \mathrm{~mL}$ and pentane $(2 \mathrm{~mL})$ was added. A yellow powder precipitated from solution at -35 ${ }^{\circ} \mathrm{C}(70 \mathrm{mg}, 57 \%) .{ }^{1} \mathrm{H}$ NMR $\left(\mathrm{C}_{6} \mathrm{D}_{6}\right) \delta 193(2 \mathrm{H}$, backbone $\mathrm{C}-\mathrm{H}), 145$ $\left(6 \mathrm{H}, 0.1, \mathrm{OCH}_{3}\right), 71\left(12 \mathrm{H}, 0.5, \mathrm{CH}_{3}\right), 37\left(4 \mathrm{H}, 1, m-\mathrm{OC}\left(\mathrm{C}_{6} \mathrm{H}_{6}\right)\right), 33$ $\left(2 \mathrm{H}, 2, p-\mathrm{OC}\left(\mathrm{C}_{6} \mathrm{H}_{6}\right)\right), 3\left(4 \mathrm{H}, 5, o-\mathrm{OC}\left(\mathrm{C}_{6} \mathrm{H}_{6}\right)\right),-9\left(12 \mathrm{H}, 1, \mathrm{CH}\left(\mathrm{CH}_{3}\right)_{2}\right)$, $-11\left(12 \mathrm{H}, 1, \mathrm{CH}\left(\mathrm{CH}_{3}\right)_{2}\right),-15(4 \mathrm{H}, 2, m-\mathrm{H}),-16(4 \mathrm{H}, 2, m-\mathrm{H}),-68$ (4H, 2, p-H), $-90\left(12 \mathrm{H}, 0.4, \mathrm{CH}\left(\mathrm{CH}_{3}\right)_{2}\right),-95\left(12 \mathrm{H}, 0.5, \mathrm{CH}\left(\mathrm{CH}_{3}\right)_{2}\right)$, $-112\left(4 \mathrm{H}, 0.1, \mathrm{CH}\left(\mathrm{CH}_{3}\right)_{2}\right),-158\left(4 \mathrm{H}, 0.1, \mathrm{CH}\left(\mathrm{CH}_{3}\right)_{2}\right) . \mu_{\mathrm{eff}}$ (Evans, $\left.\mathrm{C}_{6} \mathrm{D}_{6}\right) 6.7 \mu_{\mathrm{B}}$. Anal. Calcd. for $\mathrm{C}_{74} \mathrm{H}_{98} \mathrm{~N}_{4} \mathrm{O}_{2} \mathrm{Fe}_{2}$ : C 74.86, $\mathrm{H}$ 8.32, N 4.72. Found C 72.25, H 8.20, N 4.45. UV-vis (pentane): 486 (0.60).

$\mathbf{L}^{t \mathrm{Bu}} \mathbf{F e O C}(\mathbf{M e})(\mathbf{P h}) \mathbf{C}(\mathbf{M e})(\mathbf{P h}) \mathbf{C O F e L}^{t \mathrm{Bu}}(\mathbf{1 3})$. A $20 \mathrm{~mL}$ scintillation vial was charged with $\mathrm{L}^{\mathrm{tBu}} \mathrm{FeNNFeL}{ }^{t \mathrm{Bu}}(100 \mathrm{mg}, 87 \mu \mathrm{mol})$ and pentane $(8 \mathrm{~mL})$ to give a purple-red solution. The solution was cooled to -35 ${ }^{\circ} \mathrm{C}$, and a solution of acetophenone $(20 \mathrm{mg}, 175 \mu \mathrm{mol})$ in pentane (1 $\mathrm{mL}$ ) was added. There was no immediate change, but within $30 \mathrm{~s}$ the solution developed a yellow hue, and in $10 \mathrm{~min}$ an orange solid started to precipitate. The reaction was stirred at room-temperature overnight. The volatile materials were removed under reduced pressure, and the residue was washed with hexamethyldisiloxane $(1 \mathrm{~mL})$ to remove dark colored impurities. The remaining orange solid was redissolved in warm THF, filtered through diatomaceous earth, and cooled to $-35^{\circ} \mathrm{C}$ to give an orange powder $(60 \mathrm{mg}, 51 \%)$. The complex is insoluble in pentane and sparingly soluble in benzene. It dissolves slowly in THF. ${ }^{1} \mathrm{H}$ NMR $\left(\mathrm{C}_{6} \mathrm{D}_{6}\right) \delta 145(2 \mathrm{H}$, backbone $\mathrm{C}-H), 111\left(6 \mathrm{H}, \mathrm{OCH}_{3}\right), 38$ $\left(36 \mathrm{H}, 1, \mathrm{C}\left(\mathrm{CH}_{3}\right)_{3}\right), 34\left(4 \mathrm{H}, 1, m-\mathrm{OC}\left(\mathrm{C}_{6} \mathrm{H}_{6}\right)\right), 17\left(2 \mathrm{H}, 2, p-\mathrm{OC}\left(\mathrm{C}_{6} \mathrm{H}_{6}\right)\right)$, $3\left(4 \mathrm{H}, 4, o-\mathrm{OC}\left(\mathrm{C}_{6} \mathrm{H}_{6}\right)\right),-4(4 \mathrm{H}, 2, m-\mathrm{H}),-5(4 \mathrm{H}, 2, m-\mathrm{H}),-14(12 \mathrm{H}$, $\left.\mathrm{CH}\left(\mathrm{CH}_{3}\right)_{2}\right),-15\left(12 \mathrm{H}, \mathrm{CH}\left(\mathrm{CH}_{3}\right)_{2}\right),-45\left(4 \mathrm{H}, \mathrm{CH}\left(\mathrm{CH}_{3}\right)_{2}\right),-55(4 \mathrm{H}$, $\left.\mathrm{CH}\left(\mathrm{CH}_{3}\right)_{2}\right),-69(4 \mathrm{H}, 1, p-\mathrm{H}),-81\left(12 \mathrm{H}, 0.3, \mathrm{CH}\left(\mathrm{CH}_{3}\right)_{2}\right),-88(12 \mathrm{H}$, 0.3, $\left.\mathrm{CH}\left(\mathrm{CH}_{3}\right)_{2}\right)$. Anal. Calcd. for $\mathrm{C}_{86} \mathrm{H}_{122} \mathrm{~N}_{4} \mathrm{O}_{2} \mathrm{Fe}_{2}$ : C 76.20, $\mathrm{H} 9.07, \mathrm{~N}$ 4.13. Found C 72.60, H 8.99, N 4.18. UV-vis (THF): 519 (1.1), 492 (0.88).

$\mathbf{K}_{2} \mathbf{L}^{\text {Me }} \mathbf{F e N N F e L}{ }^{M e}$ (14). A flask was charged with $L^{\mathrm{Me}} \mathrm{Fe}$ $(\mu-\mathrm{Cl})_{2} \mathrm{FeL}^{\mathrm{Me} 60 \mathrm{~b}}(2.50 \mathrm{~g}, 2.46 \mathrm{mmol})$ and pentane $(25 \mathrm{~mL}) . \mathrm{KC}_{8}(1.39$ $\mathrm{g}, 10.3 \mathrm{mmol}$ ) was added to the yellow slurry, leading to the formation of a very dark blue solution. The reaction mixture was stirred overnight at room temperature and filtered through diatomaceous earth to give a dark blue solution. The solution was concentrated to $15 \mathrm{~mL}$ and cooled to $-35^{\circ} \mathrm{C}$ to give dark blue crystals $(1.21 \mathrm{~g}, 43 \%)$. ${ }^{1} \mathrm{H}$ NMR $\left(\mathrm{C}_{6} \mathrm{D}_{6}\right)$ $\delta 25(8 \mathrm{H}, 5, m-\mathrm{H}), 3\left(12 \mathrm{H}, 1, \mathrm{CH}_{3}\right), 1\left(24 \mathrm{H}, 1, \mathrm{CH}\left(\mathrm{CH}_{3}\right)_{2}\right),-1(24 \mathrm{H}$, $\left.1, \mathrm{CH}\left(\mathrm{CH}_{3}\right)_{2}\right),-38(4 \mathrm{H}, 1, p-\mathrm{H}),-82(2 \mathrm{H}, 0.5$, backbone $\mathrm{C}-\mathrm{H}),-305$ $\left(8 \mathrm{H}, 0.2, \mathrm{CH}\left(\mathrm{CH}_{3}\right)_{2}\right) . \mu_{\text {eff }}$ (Evans, $\left.\mathrm{C}_{6} \mathrm{D}_{6}\right) 4.9 \mu_{\mathrm{B}}$. Anal. Calcd for $\mathrm{C}_{58} \mathrm{H}_{82} \mathrm{~N}_{6} \mathrm{Fe}_{2} K_{2}$ : C 66.14, H 7.85, N 7.98. Found C 66.19, H 7.86, N 6.48. UV-vis (pentane): 722 (11.4), 486 (7.7), 449 (8.5), 369 (17).

$\mathbf{L}^{t \mathrm{Bu}} \mathbf{F e}(\boldsymbol{\mu}$-Cl)K(18-crown-6) (15). In an argon-filled glovebox, a 20 $\mathrm{mL}$ scintillation vial was charged with $\mathrm{L}^{t \mathrm{Bu}} \mathrm{FeCl}(200 \mathrm{mg}, 337 \mu \mathrm{mol})$, 18-crown-6 (89 mg, $337 \mu \mathrm{mol})$ and $\mathrm{Et}_{2} \mathrm{O}(10 \mathrm{~mL})$ to give a red solution. To this solution was added $\mathrm{KC}_{8}(50 \mathrm{mg}, 370 \mu \mathrm{mol})$, resulting in the immediate formation of a dark green solution and black graphite. The reaction was stirred at room-temperature overnight and filtered through diatomaceous earth to give a dark green solution. The solvent was removed in vacuo to give a dark green solid. This solid was dissolved in toluene $(4 \mathrm{~mL})$, layered with pentane $(2 \mathrm{~mL})$ and cooled to $-35{ }^{\circ} \mathrm{C}$ to give dark green crystals $(103 \mathrm{mg}, 35 \%) .{ }^{1} \mathrm{H}$ NMR $\left(\mathrm{C}_{6} \mathrm{D}_{6}\right) \delta 48(4 \mathrm{H}$, $\left.\mathrm{CH}\left(\mathrm{CH}_{3}\right)_{2}\right), 10\left(18 \mathrm{H}, \mathrm{C}\left(\mathrm{CH}_{3}\right)_{3}\right), 6\left(24 \mathrm{H},\left(\mathrm{OCH}_{2} \mathrm{CH}_{2}\right)_{6}\right), 3(12 \mathrm{H}, \mathrm{CH}-$ $\left.\left(\mathrm{CH}_{3}\right)_{2}\right), 2(4 \mathrm{H}, m-\mathrm{H}),-8\left(12 \mathrm{H}, \mathrm{CH}\left(\mathrm{CH}_{3}\right)_{2}\right),-44(2 \mathrm{H}, p-\mathrm{H}),-61(1 \mathrm{H}$, backbone $\mathrm{C}-H) .{ }^{1} \mathrm{H}$ NMR $\left(\mathrm{THF}-\mathrm{d}_{8}\right) \delta 43(4 \mathrm{H}, m-\mathrm{H}), 7\left(18 \mathrm{H}, \mathrm{C}\left(\mathrm{CH}_{3}\right)_{3}\right)$, $5\left(24 \mathrm{H},\left(\mathrm{OCH}_{2} \mathrm{CH}_{2}\right)_{6}\right), 0.02\left(12 \mathrm{H}, \mathrm{CH}\left(\mathrm{CH}_{3}\right)_{2}\right),-2\left(2 \mathrm{H}, \mathrm{CH}\left(\mathrm{CH}_{3}\right)_{2}\right)$, $-9\left(14 \mathrm{H}, \mathrm{CH}\left(\mathrm{CH}_{3}\right)_{2}, \mathrm{CH}\left(\mathrm{CH}_{3}\right)_{2}\right),-56(2 \mathrm{H}, p-\mathrm{H}),-165(1 \mathrm{H}$, backbone C- $H$ ). $\mu_{\text {eff }}$ (Evans, $\left.\mathrm{C}_{6} \mathrm{D}_{6}\right) 3.6(3) \mu_{\text {eff. }}$

Reduction of $\mathbf{L}^{t \mathrm{Bu}} \mathbf{F e C l}$ under Argon. In an argon-filled glovebox, a $20 \mathrm{~mL}$ scintillation vial was charged with $\mathrm{L}^{\mathrm{tBu}} \mathrm{FeCl}(20 \mathrm{mg}, 34 \mu \mathrm{mol})$ and THF- $d_{8}(0.5 \mathrm{~mL})$ to give an orange solution. Solid $\mathrm{KC}_{8}(5 \mathrm{mg}, 37$ $\mu \mathrm{mol}$ ) was added, resulting in the immediate formation of a dark green solution and black graphite. The reaction was stirred at room temperature for $3 \mathrm{~h}$, and then filtered through diatomaceous earth into a resealable NMR tube. The ${ }^{1} \mathrm{H}$ NMR spectrum was recorded. ${ }^{1} \mathrm{H}$ NMR $\left(\mathrm{THF}-d_{8}\right) \delta 55(4 \mathrm{H}, m-\mathrm{H}), 16\left(18 \mathrm{H}, \mathrm{C}\left(\mathrm{CH}_{3}\right)_{3}\right), 8\left(2 \mathrm{H}, \mathrm{CH}\left(\mathrm{CH}_{3}\right)_{2}\right), 4$ $\left(\mathrm{O}\left(\mathrm{CH}_{2} \mathrm{CH}_{2}\right)_{2}\right), 1\left(\mathrm{O}\left(\mathrm{CH}_{2} \mathrm{CH}_{2}\right)_{2}\right),-1\left(2 \mathrm{H}, \mathrm{CH}\left(\mathrm{CH}_{3}\right)_{2}\right),-5(12 \mathrm{H}, \mathrm{CH}-$ $\left.\left(\mathrm{CH}_{3}\right)_{2}\right),-14\left(6 \mathrm{H}, \mathrm{CH}\left(\mathrm{CH}_{3}\right)_{2}\right),-27\left(6 \mathrm{H}, \mathrm{CH}\left(\mathrm{CH}_{3}\right)_{2}\right),-73(2 \mathrm{H}, p-\mathrm{H})$, $-119(1 \mathrm{H}$, backbone $\mathrm{C}-H)$. The tube was frozen and placed under vacuum and $\mathrm{N}_{2}$ was introduced into the tube. The green solution became red-purple within 2 min, and signals characteristic of $\mathrm{L}^{t \mathrm{Bu}} \mathrm{FeNNFe} \mathrm{L}^{t \mathrm{Bu}}$ were observed in the ${ }^{1} \mathrm{H}$ NMR spectrum.

Reaction of $\mathbf{K}_{2} \mathbf{L}^{\mathrm{Me}} \mathbf{F e N N F e L}{ }^{\mathrm{Me}}$ with $\mathbf{C H}_{3} \mathrm{OTf}$. $\mathrm{K}_{2} \mathrm{~L}^{\mathrm{Me}} \mathrm{FeNNFe} \mathrm{L}^{\mathrm{Me}}$ $(10 \mathrm{mg}, 9 \mu \mathrm{mol})$ and $\mathrm{C}_{6} \mathrm{D}_{6}$ (ca. $0.5 \mathrm{~mL}$ ) were added to a resealable NMR tube. Methyl triflate $(2.0 \mu \mathrm{L}, 18 \mu \mathrm{mol})$ was added via syringe to the dark blue solution. Gas evolution was observed, and the solution became yellow orange in color with the formation of a white solid. ${ }^{1} \mathrm{H}$ NMR spectroscopy revealed the quantitative formation of $\mathrm{L}^{\mathrm{Me}} \mathrm{FeMe} .^{28 \mathrm{~b}}$

X-ray Structural Determinations. Crystalline samples of all the complexes were grown in the glovebox from pentane solutions at -35 ${ }^{\circ} \mathrm{C}$. All crystals were rapidly mounted under Paratone- 8277 onto glass fibers, and immediately placed in a cold nitrogen stream at $-80{ }^{\circ} \mathrm{C}$ on the X-ray diffractometer. The X-ray intensity data were collected on a standard Bruker-axs SMART CCD Area Detector System equipped with a normal focus molybdenum-target X-ray tube operated at 2.0 $\mathrm{kW}(50 \mathrm{kV}, 40 \mathrm{~mA})$. A total of 1321 frames of data (1.3 hemispheres) were collected using a narrow frame method with scan widths of $0.3^{\circ}$ in $\omega$ and exposure times of $30 \mathrm{~s} /$ frame, using a detector-to-crystal distance of $5.09 \mathrm{~cm}$. Frames were integrated to a maximum $2 \theta$ angle of $56.5^{\circ}$ with the Bruker-axs SAINT program. The final unit cell parameters (at $-80{ }^{\circ} \mathrm{C}$ ) were determined from the least-squares refinement of three-dimensional centroids of $>3400$ reflections for each crystal. Data were corrected for absorption with the SADABS program, except when noted otherwise. The space groups were assigned using XPREP, and the structures were solved by direct methods using Sir $92^{42}$ (WinGX v1.63.02) and refined employing full-matrix least-squares on $\mathrm{F}^{2}$ (Bruker-axs, SHELXTL-NT, version 5.10). Nonhydrogen atoms were refined with anisotropic thermal parameters, except disordered solvent in some cases. Hydrogen atoms were included in idealized positions with riding thermal parameters. Details are provided in Table 2 and the Supporting Information.

Computational Methods. The calculations reported herein employed the GAMESS ${ }^{61}$ and Jaguar ${ }^{62}$ packages. GAMESS was used for multireference calculations and Jaguar for density functional theory (DFT) calculations. The Stevens effective core potentials and valence basis sets were employed, ${ }^{63}$ augmented with a d polarization function on main group elements. Hydrogen was described with the $-31 \mathrm{G}$ basis set. For density functional calculations the $\mathrm{B}^{2} \mathrm{LYP}^{64}$ hybrid functional was used. This combination of theory level and basis sets was used in previous calculations on iron- $\beta$-diketiminate-dinitrogen complexes. ${ }^{25}$

Multireference calculations ${ }^{44}$ were used to cross-reference the ground state multiplicities obtained by experiment and density functional methods given the density of low energy states in these complexes. The active space was chosen to include all orbitals (and the electrons contained therein) needed to describe the Fe-dinitrogen moiety. All multireference calculations were performed within the FORS (fully optimized reaction space) paradigm, i.e., all possible configuration state functions, within the limits of spatial and spin symmetry, were generated for the active space of interest. For multireference Møller-Plesset 2nd

(60) (a) Smith, J. M.; Lachicotte, R. J.; Holland, P. L. Chem. Commun. 2001 1542-1543. (b) Eckert, N. A.; Smith, J. M.; Lachicotte, R. J.; Holland, P. L. Inorg. Chem. 2004, 43, 3306-3321.

(61) Schmidt, M. W.; Baldridge, K. K.; Boatz, J. A.; Elbert, S. T.; Gordon, M S.; Jensen, J. H.; Koseki, S.; Matsunaga, N.; Nguyen, K. A.; Su, S.; Windus, T. L.; Dupuis, M.; Montgomery, J. A. J. Comput. Chem. 1993, 14, 13471363 .

(62) Jaguar, version 5.5, Schrödinger, 1500 S. W. First Avenue, Suite 1180, Portland, OR 97201, http://www.schrodinger.com.

(63) Stevens, W. J.; Krauss, M.; Basch, H.; Jasien, P. G. Can. J. Chem. 1992 $70,612-613$

(64) Becke, A. D. J. Chem. Phys. 1993, 98, 5648-5652; Lee, C.; Yang, W Parr, R. G. Phys. Rev. B 1988, 37, 785-789; Vosko, S. H.; Wilk, L.; Nusair, M. Can. J. Phys. 1980, 58, 1200-1211. 
order perturbation theory (MRMP2) calculations, single and double excitations from the FORS active space to the remaining virtual orbitals were allowed.

Geometry optimization calculations utilized the B3LYP functional and density-functional methods given the much greater computational tractability of DFT in relation to MCSCF and MRMP2 methods. In all cases, the ground-state multiplicities predicted by B3LYP agree with those obtained from MCSCF and MRMP2 calculations. DFT calculations were performed within the restricted open-shell (RODFT) paradigm to obviate spin contamination issues.

Resonance Raman Spectroscopy. Resonance Raman spectra were obtained from 10 to $20 \mathrm{mM}$ solutions contained in a 5-mm NMR tube spinning at $\sim 20 \mathrm{~Hz}$. Raman scattering was excited using $406.7 \mathrm{~nm}$ emission from a $\mathrm{Kr}^{+}$laser ( 15 to $35 \mathrm{~mW}$ ). Spectra were recorded at ambient temperature using $135^{\circ}$ backscattering geometry with the laser beam focused to a line. Scattered light was collected with an $f 1$ lens and filtered with a holographic notch filter to attenuate Rayleigh scattering. The polarization of the scattered light was then scrambled and the spot image was $f$-matched to a $0.63 \mathrm{~m}$ spectrograph fitted with a 2400 groove $/ \mathrm{mm}$ grating and a $\mathrm{LN}_{2}$-cooled CCD camera. The spectrometer was calibrated using the Raman bands of toluene, pentane, acetone, and $d^{6}$-DMSO as external frequency standards.

Acknowledgment. Funding for this work was provided by the National Science Foundation (CHE-0309811 to T.R.C. and CHE-0112658 to P.L.H.), National Institutes of Health (GM065313 to P.L.H.), A. P. Sloan Foundation (Research Fellowship to P.L.H.), USDA (ND05299 to K.R.R.), and Hermann Frasch Foundation (446-HF97 to K.R.R.). We thank Cambridge Isotopes for a generous gift of ${ }^{15} \mathrm{~N}_{2}$.

Supporting Information Available: Variable-temperature NMR spectra and crystallographic details. This material is available free of charge via the Internet at http://pubs.acs.org.

JA052707X 